\title{
Ligand-induced cleavage and regulation of nuclear entry of Notch in D rosophila melanogaster embryos
}

\author{
Simon Kidd, ${ }^{1}$ Toby Lieber, ${ }^{1}$ and Michael W. Young ${ }^{2}$ \\ Laboratory of Genetics, The Rockefeller University, N ew York, N ew York 10021-6399 USA
}

\begin{abstract}
Notch, a transmembrane protein found in a wide range of organisms, is a component of a pathway that mediates cell-fate decisions that involve intercellular communication. In this paper, we show that in D rosophila melanogaster, Notch $(\mathrm{N})$ is processed in a ligand-dependent fashion to generate phosphorylated, soluble intracellular derivatives. Suppressor of Hairless [Su(H)] is predominantly associated with soluble intracellular $\mathbf{N}$. It has been demonstrated by others that $\mathbf{N}$ has access to the nucleus, and we show that when tethered directly to DNA, the cytoplasmic domain of $\mathrm{N}$ can activate transcription. Conversely, a viral activator fused to $\mathrm{Su}(\mathrm{H})$ can substitute for at least some $\mathrm{N}$ functions during embryogenesis. We suggest that one function of soluble forms of $\mathbf{N}$ is to bind to $\mathrm{Su}(\mathrm{H})$, and in the nucleus, to act directly as a transcriptional transactivator of the latter protein. Although $\mathrm{N}$ has functional nuclear localization signals, the $\mathrm{N} / \mathrm{Su}(\mathrm{H})$ complex accumulates in the cytoplasm and on membranes suggesting that its nuclear entry is regulated. Localization studies in cultured cells and embryos suggest that $\mathrm{Su}(\mathrm{H})$ plays a role in this regulation, with the relative levels of Delta, $\mathbf{N}$ and Su(H) determining whether a $\mathbf{N} / \mathrm{Su}(\mathrm{H})$ complex enters the nucleus.
\end{abstract}

[Key Words: N otch; processing; Delta; Suppressor of Hairless; nuclear entry; transcriptional transactivator]

Received September 14, 1998; revised version accepted October 20, 1998.

$\mathrm{N}$ otch $(\mathrm{N})$ is a 2703-amino-acid transmembrane protein that is found in a wide range of organisms from Caenorhabditis elegans to humans. The $\mathrm{N}$ gene was originally identified in Drosophila melanogaster in which $\mathrm{N}$ is a component of a pathway involved in cell-fate decisions that involve intercellular communication. During Drosophila embryogenesis, this process, which is known as lateral inhibition, operates in all three germ layers and ensures that only one cell of several equipotential cells, termed an equivalence group, will adopt the primary cell fate. Because this pathway was first characterized in the neuroectoderm, in which the absence of any member of the pathway results in overproliferation of neuroblasts, the genes involved in lateral inhibition are known as neurogenic genes. $\mathrm{N}$, and other members of the neurogenic gene family are also conserved during evolution (for review, see Artavanis-Tsakonas et al. 1995; Greenwald 1998).

Genetic mosaic analysis has demonstrated that $\mathrm{N}$ is cell autonomous, suggesting that it is a receptor (Hoppe 1986; Heitzler and Simpson 1991). Delta (DI), also a transmembrane protein, has been identified as the ligand for $\mathrm{N}$ in its role in lateral inhibition (for review, see Artavanis-T sakonas et al. 1995; N ye and Kopan 1995). Ac-

\footnotetext{
${ }^{1}$ These authors contributed equally to this work.

${ }^{2}$ Corresponding author.

E-MAIL young@rockvax.rockefeller.edu; FAX 212-327-8695.
}

tivation of $\mathrm{N}$ results in transcription of genes of the Enhancer of split [E(spl)]) complex. This transcriptional activation is mediated by Suppressor of Hairless $(\mathrm{Su}(\mathrm{H}))$, a DNA binding protein that has been demonstrated to bind to the cytoplasmic domain of N (Fortini and Artavanis-T sakonas 1994; Jennings et al. 1994; Jarriault et al. 1995; Lecourtois and Schweisguth 1995; Tamura et al. 1995; Kato et al. 1997; Schroeter et al. 1998).

Previous work has shown that expression of $\mathrm{N}$ proteins deleted for the extracellular domain results in gain of function phenotypes indicative of ligand-independent activation (for review, see Artavanis-Tsakonas et al. 1995; Greenwald 1998). The cytoplasmic domain of N contains functional nuclear localization signals (Stifani et al. 1992; Lieber et al. 1993), and it has been proposed that on binding $\mathrm{DI}$, the transmembrane $\mathrm{N}$ protein is cleaved releasing the cytoplasmic domain that translocates to the nucleus, where it is tethered to DNA via $\mathrm{Su}(\mathrm{H})$ and behaves as a transcriptional transactivator (Lieber et al. 1993; Struhl et al. 1993; Jarriault et al . 1995; Kopan et al. 1996). In tissue culture, Schroeter et al. (1998) have mapped a si te in the transmembrane domain of mouse N otch-1 at which it undergoes ligand-dependent proteolytic cleavage. Mutating this site reduces the activity of N otch- 1 in cell culture. In addition, it has been found that in vivo the cytoplasmic domain of Drosophila $\mathrm{N}$ has access to the nucleus, although the biochemical nature of this access was not determined (Lecourtois and Schwei sguth 1998; Struhl and Adachi 1998). 
In this paper, we present data indicating that in wildtype Drosophila, $\mathrm{N}$ is processed in a ligand-dependent manner to generate a cytoplasmic domain that, on the basis of size and sol ubility, does not span the membrane. This domain is phosphorylated and $\mathrm{Su}(\mathrm{H})$ preferentially associates with this form. The N/Su(H) compl ex is found associated with membranes and predominantly in the cytoplasm, indicating that there is a mechanism for regulating its subcellular location. Our data suggest that $\mathrm{Su}(\mathrm{H})$ can inhibit nuclear entry of the soluble N proteins, and that nuclear entry occurs in a fashion dependent on the relative abundance of soluble $\mathrm{N}$ and $\mathrm{Su}(\mathrm{H})$. In prior genetic studies of $\mathrm{N}$ nuclear activity, it was suggested that nuclear $\mathrm{N}$ participates in the transcriptional regulation of downstream target genes (Lecourtois and Schweisguth 1998; Struhl and Adachi 1998). We show that in the nucleus, $\mathrm{N}$ behaves as a transcriptional transactivator, and that a heterologous activator fused to $\mathrm{Su}(\mathrm{H})$ can substitute for activated $\mathrm{N}$ function in embryos.

\section{Results}

\section{$\mathrm{Su}(\mathrm{H})$ interacts with phosphorylated Notch proteins}

$\mathrm{N}$ and $\mathrm{Su}(\mathrm{H})$ proteins have been shown to physically interact (Fortini and Artavanis-T sakonas 1994; Jarriault et al. 1995; Tamura et al. 1995; Kato et al. 1997; Schroeter et al. 1998). To characterize the nature of the associated $\mathrm{N}$ and $\mathrm{Su}(\mathrm{H})$ proteins in vivo, immunoprecipitations with antibodies against either $\mathrm{N}$ or $\mathrm{Su}(\mathrm{H})$ were performed on detergent extracts of Drosophila embryos. Following el ectrophoresis, $\mathrm{N}$ proteins in these immunoprecipitates were detected by Western blot. When anti-N and anti-Su(H) immunoprecipitations are probed with anti-N antibodies, only a small subset of the proteins immunoprecipitated by anti-N antibodies are found in the corresponding $\mathrm{Su}(\mathrm{H})$ immunopreci pitate [cf. Fig. 2A, below, lanes 1 and 2, anti-Su(H) immunoprecipitation, with Fig. 2C, lanes 1 and 2, anti-N immunoprecipitation]. This suggests that the interactions between $\mathrm{N}$ and $\mathrm{Su}(\mathrm{H})$ detected in this assay occurred in vivo and not during the course of the immunoprecipitation, as the latter might be expected to result in similar array of $\mathrm{N}$ proteins in both immunoprecipitates.

Anti-Su(H) immunoprecipitates contain two major size classes of $\mathrm{N}$ proteins, both of which are recognized by antibodies raised against 2 different regions of the intracellular domain of $\mathrm{N}$ (see Fig. 1 for antibodies used in this work); one the size of full length $\mathrm{N}$ and another, substantially enriched, which migrates as smear of proteins of $\sim 114$ kD (Fig. 2A, lane 1). The existence of a smear of bands at $114 \mathrm{kd}$ suggests that these $\mathrm{N}$ proteins might be post-translational ly modified, perhaps by phosphorylation. Figure 2A, Iane 2, shows that treating the $\mathrm{Su}(\mathrm{H})$ immunopreci pitates with alkal ine phosphatase results in the smear of proteins being resolved into three proteins of $100 \mathrm{kD}$, which we have termed in order of decreasing molecular weight $\mathrm{N}^{\mathrm{p} 100 \mathrm{~A}}, \mathrm{~N}^{\mathrm{p} 100 \mathrm{~B}}$, and $\mathrm{N}^{\mathrm{p} 100 \mathrm{C}} \cdot \mathrm{N}^{\mathrm{plOOA}}$ and $\mathrm{N}^{\mathrm{plo0C}}$ differ by $\sim 4 \mathrm{kD}$. We have

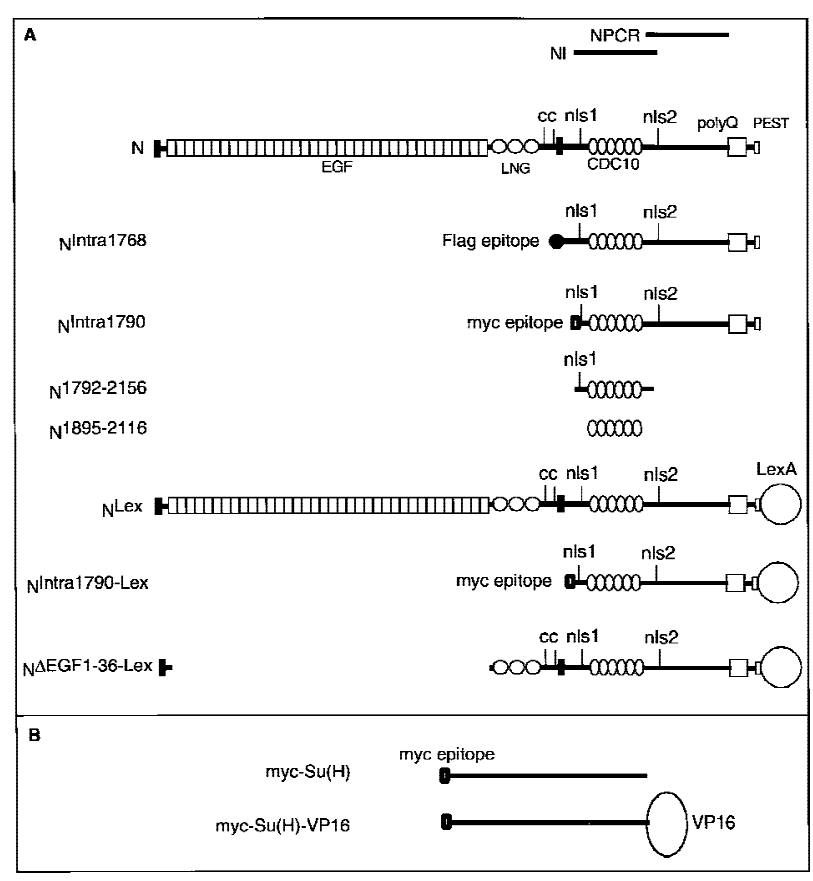

Figure 1. Constructs and antibodies. (A) A diagram of the $\mathrm{N}$ protein (N). (EGF) Epidermal growth factor-like repeats; (LNG) lin-12, N otch, GIp-1 repeats; (cc) evolutionary conserved cysteine residues; (CDC10) CDC10 or ankyrin repeats; (nls1, nls2) putative nuclear localization signals; (polyQ) polymeric glutamines; (PEST) PEST sequence thought to be involved in protein stability (Rogers et al. 1986). The bars above the diagram of $\mathrm{N}$ indicate the various regions used as antigens to create anti- $\mathrm{N}$ antibodies. Beneath the diagram of $\mathrm{N}$ are the $\mathrm{N}$ constructs used in this paper. (B) $\mathrm{Su}(\mathrm{H})$ constructs used in this paper.

collectively termed the phosphorylated forms of these proteins $\mathrm{N}^{\text {pp114 }}$. Treatment of the immunoprecipitates with alkaline phosphatase in the presence of phosphatase inhibitors reduces the effect of the phosphatase (Fig. $2 \mathrm{~A}$, lane 3 ). Because $\mathrm{N}^{\text {pp114 }}$ reacts with two different $\mathrm{N}$ antibodies, it is most likely that these proteins are N. As no alternatively spliced $\mathrm{N}$ transcripts have been observed, and no appropriately positioned methionine exists at which internal translation could initiate to give rise to a protein with the size and antigenic determinants of $\mathrm{N}^{\text {pp114 }}$ (Wharton et al . 1985; Kidd et al. 1986; Kopan et al. 1996), it is most likely that these smaller $\mathrm{N}$ proteins are the result of proteolytic cleavage.

The proteins used for the previous experiment were from an overnight collection of embryos. We wondered if production of the various $\mathrm{N}$ proteins associated with $\mathrm{Su}(\mathrm{H})$ is devel opmentally regulated. Figure $2 \mathrm{~B}$ shows that whereas $\mathrm{N}^{\text {pp114 }}$ is present throughout embryogenesis with $\mathrm{N}^{\mathrm{p} 100 \mathrm{~B}}$ as its major component, the amount of $\mathrm{N}^{\text {p100A }}$ appears to increase with age, and $\mathrm{N}^{\text {p100C }}$ is only found late in embryogenesis. In addition, embryos that are young (0-4 hr) contain significantly more processed $\mathrm{N}$ protein that comigrates with hypophosphorylated $\mathrm{N}^{\text {p100B }}$ (indicated by an asterisk) relative to $\mathrm{N}^{\text {pp114 }}$. Late in embryogenesis, proteins that comigrate with both hypophosphorylated $\mathrm{N}^{\mathrm{p} 100 \mathrm{~B}}$ and $\mathrm{N}^{\mathrm{p} 100 \mathrm{C}}$ are found. 

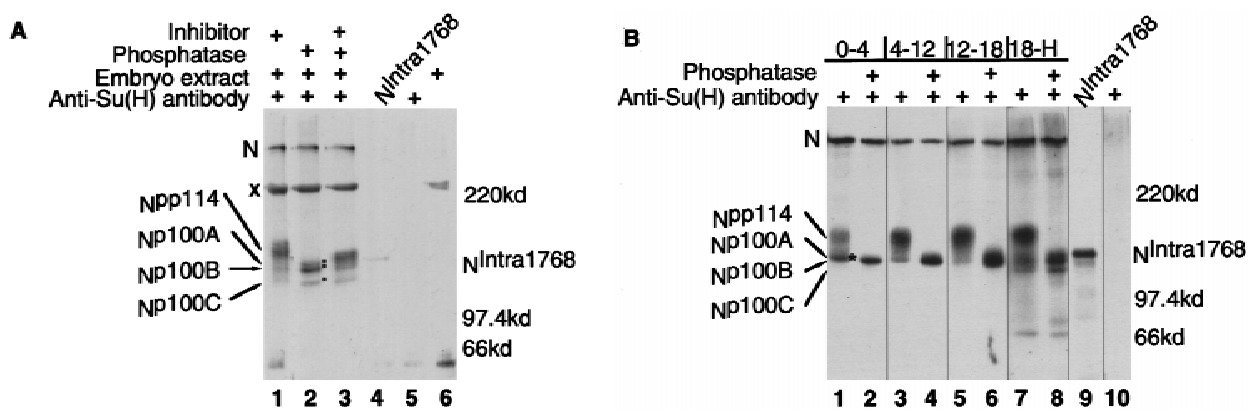

Figure 2. $\mathrm{Su}(\mathrm{H})$ is associated with phosphorylated $N$ proteins. $(A, B)$ Western blot analysis of anti-Su(H) immunoprecipitates from Drosophila embryos probed with anti-N (N PCR) antibody. For A, an overnight collection of embryos was used and in B, staged embryos (age indicated in hours at top of lanes; $H$ denotes hatching) were used for detergent extracts. Prior to electrophoresis, some of the samples were treated with alkaline phosphatase with or without inhibitor. (+) Presence of phosphatase and/or inhibi-

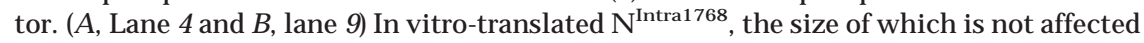
by phosphatase treatment; (A, lane 5) A nti body but no extract; (A, lane 6) Embryo extract recovered on protein $A$-Sepharose beads that were not conjugated to antibody. The locations of $\mathrm{N}(\mathrm{N}), \mathrm{N}^{\text {Intra1768 }}, \mathrm{N}^{\mathrm{pp114}}, \mathrm{N}^{\mathrm{p} 100 \mathrm{~A}}, \mathrm{~N}^{\mathrm{p} 100 \mathrm{~B}}$, and $\mathrm{N}^{\mathrm{p} 100 \mathrm{C}}$ proteins are shown al ong side each blot, and also by dots on the blot. The $x$ in $A$ indicates a cross-reacting protein nonspecifically bound to the protein A-Sepharose beads; the asterisk $(*)$ in $B$ indicates a hypophosphorylated $\mathrm{N}$ protein that comigrates with $\mathrm{N}^{\mathrm{p100B}}$. (A, all lanes with extract;

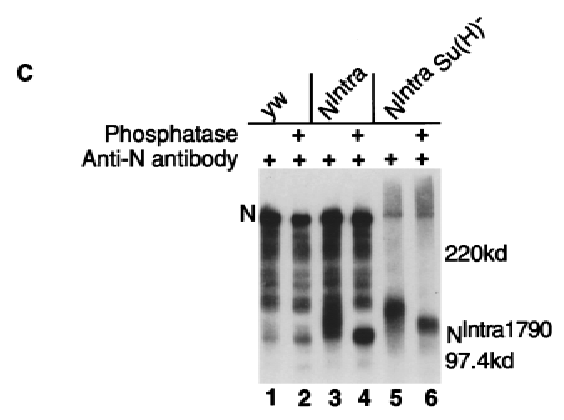
B, lanes 3-6) $500 \mu \mathrm{g}$ of protein was used for each immunoprecipitation; the remaining lanes in B contain 2.5 mg(lanes 1,2) and 1.75 mg (lanes 7,8). (C) Western blot analysis of anti-N (NI) immunoprecipitates from Drosophila embryos probed with anti-N (N PCR) anti body. (Lanes 1, 2) Immunopreci pitates from yw embryos; (lanes 3,4) immunopreci pitates of embryos resulting from a cross of Su(H)

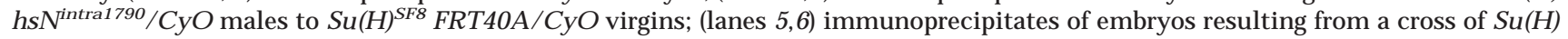

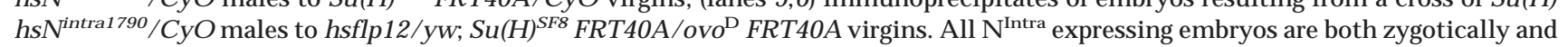
maternally $\mathrm{Su}(\mathrm{H})$ null. For all genotypes, 3- to $5 \mathrm{hr}$-old embryos were subjected to a $30 \mathrm{~min}$ heat shock at $37^{\circ} \mathrm{C}$ and allowed to recover for 15-30 min prior to collection. (+) Phosphatase treatment. The locations of $\mathrm{N}(\mathrm{N})$ and $\mathrm{N}^{\text {Intra }}$ are indicated next to the blot.

The above experiment indicates that phosphorylated, processed $\mathrm{N}$ proteins interact with $\mathrm{Su}(\mathrm{H})$. To address whether phosphorylation is a consequence of $\mathrm{Su}(\mathrm{H})$ binding, we asked whether $\mathrm{N}^{\text {Intra1790 }}$ (Fig. 1) is phosphorylated in embryos that lack $\mathrm{Su}(\mathrm{H})$. As can be seen in Figure $2 \mathrm{C}$, lanes 5 and $6, \mathrm{~N}^{\text {Intra1790 }}$ expressed in embryos that are both maternally and zygotically $\mathrm{Su}(\mathrm{H})^{-}$is phosphorylated, indicating that phosphorylation of processed $\mathrm{N}$ proteins is not dependent on $\mathrm{Su}(\mathrm{H})$ binding. Intriguing$\mathrm{ly}$, even after phosphatase treatment, $\mathrm{N}^{\text {Intra1790 }}$ immunoprecipitated from $\mathrm{Su}(\mathrm{H})^{-}$embryos migrates slower than $\mathrm{N}^{\text {Intra1790 }}$ immunoprecipitated from embryos that contain $\mathrm{Su}(\mathrm{H})$ (cf. lanes 4 and 6). This might be because $\mathrm{N}^{\text {Intra1790 }}$ bound to $\mathrm{Su}(\mathrm{H})$ has undergone additional proteolytic processing, or $\mathrm{N}^{\text {intra1790 }}$ not bound to $\mathrm{Su}(\mathrm{H})$ has been subject to additional post-translational modification. However, in the $\mathrm{Su}(\mathrm{H})^{-}$extracts there is also a smear extending upward from endogenous $\mathrm{N}$. This suggests that in $\mathrm{Su}(\mathrm{H})^{-}$embryos, $\mathrm{N}^{\text {Intra1790 }}$, as well as being phosphorylated, has undergone additional post-translational modification.

We have also analyzed $\mathrm{Su}(\mathrm{H})$ coimmunoprecipitated with anti-N antibodies (data not shown). The Su(H) associated with $\mathrm{N}$ comigrates with the $\mathrm{Su}(\mathrm{H})$ immunoprecipitated by anti-Su(H) antibodies. In both immunoprecipitates, there is no change in mobility on phosphatase treatment, suggesting that $\mathrm{Su}(\mathrm{H})$ is not extensively phosphorylated.

\section{Cleavage of $\mathrm{N}$ is ligand dependent}

If $\mathrm{N}$ signaling is dependent on ligand-induced cleavage of $\mathrm{N}$, then $\mathrm{N}^{\mathrm{pp} 114}$ might result from the binding of a $\mathrm{N}$ ligand. The two experiments shown in Figure 3 demonstrate that the presence of ligand and the ability of $\mathrm{N}$ to bind ligand is required for the presence of $\mathrm{N}^{\mathrm{pp} 114}$. All the known $\mathrm{N}$ ligands bind to the extracellular EGF-like repeats, deletion of which results in a nonfunctional protein (Rebay et al. 1991, 1993; Li eber et al. 1993). Extracts from embryos expressing a form of $\mathrm{N}$ that spans the membrane but lacks the EGF-like repeats and is tagged at the $C$ arboxyl terminus with the DN A-binding domain of LeXA [N ${ }^{\triangle E G F 1-36-L e x A}$ (Fig. 1)] were immunoprecipitated with anti-N and anti-Su(H) antibodies, treated with phosphatase, and the Western blot probed with anti-LexA antibody. As can be seen in Figure 3A, lane 4, the anti$\mathrm{Su}(\mathrm{H})$ immunoprecipitates from $\mathrm{N}^{\Delta \mathrm{EGF1}-36-\mathrm{LexA}}$ embryos do not contain $\mathrm{N}^{\text {p100-LexA }}$. Expression of $\mathrm{N}^{\mathrm{EEGF1-36-LexA}}$ will not rescue the neurogenic phenotype of a zygotically $\mathrm{N}^{-}$embryo (data not shown). As a control for this experiment, immunoprecipitations from embryos expressing LexA-tagged $N\left(N^{\text {LexA }}\right.$ ) were carried out. In these experiments, a LexA-tagged $\mathrm{N}^{\mathrm{p} 100}$ protein is seen (Fig. 3A, Iane $3, \mathrm{~N}^{\mathrm{p} 100-\mathrm{LexA}}$, indicated by an asterisk, presumably the hypophosphorylated form of $\mathrm{N}^{\text {pp114-LexA }}$ ). Expression of $\mathrm{N}^{\text {LexA }}$ will rescue the neurogenic phenotype of zygotically $\mathrm{N}^{-}$embryos (data not shown). 

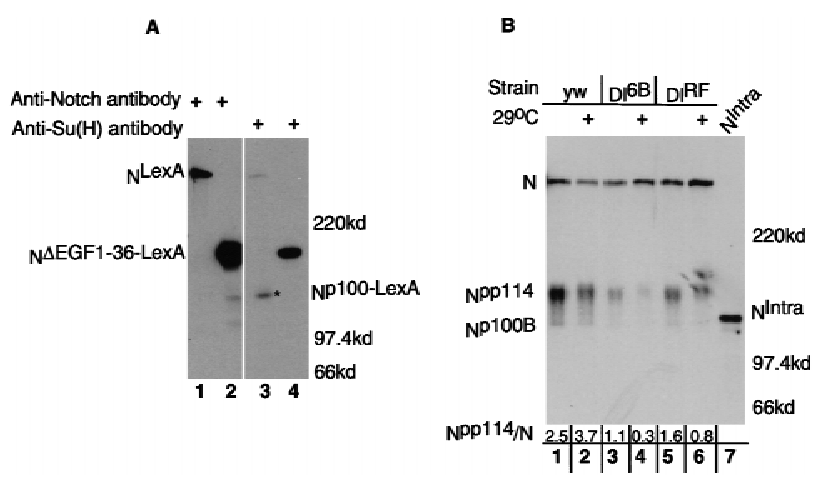

Figure 3. The presence of $\mathrm{N}$ otch ligand and the extracellular domain of $\mathrm{N}$ are required for the isolation of $\mathrm{N}^{\mathrm{p} 100}$ bound to $\mathrm{Su}(\mathrm{H})$. (A) Detergent extracts from embryos expressing either $\mathrm{N}^{\text {LexA }}$ (lanes 1,3) or $\mathrm{N}^{\triangle \mathrm{EEGF1}-36-L e x A}$ [lanes 2,4 (see Fig. 1 for structures of $N^{\text {LexA }}$ and $N^{\triangle E G F 1-36-L e x A}$ ] were immunoprecipitated with antibodies against either N (NI) (lanes 1,2) or Su(H) (lanes 3,4 ) treated with phosphatase, and then probed with antibodies against LexA. Antibodies against $\mathrm{N}$ immunoprecipitate $\mathrm{N}^{\text {LexA }}$ (lane 1) and N ${ }^{\triangle E G F 1-36-L e x A}$ (lane 2); the smaller proteins seen in lane 2 are missing from lane 1 and, are most likely nonspecific breakdown products visible because of massive overexpression of $N^{\Delta E G F 1-36-L e x A}$ compared with $N^{\text {LexA }}$. $N^{\text {LexA }}$ and $N^{\triangle E G F 1-36-L e X A}$ are coimmunoprecipitated by anti-Su(H) antibodies as is a smaller, processed form of $N^{\text {LexA }}$ ( $\mathrm{N}^{\text {p100-LEXA, }}$ lane $3, *)$. N o such processed protein is seen when the extracelIular ligand binding domain of $\mathrm{N}$ is deleted (lane 4). (B) DI temperature-sensitive mutants reduce the level of processed $\mathrm{N}$ protein. yw (wt), DI ${ }^{6 \mathrm{~B}} / \mathrm{TM} 6$ (a strong) or DI ${ }^{\mathrm{RF}} / \mathrm{TM} 6$ (a weak temperature-sensitive DI allele) males were mated to DIT/TM 6 (an amorphic DI allele) females. All the embryos resulting from the above crosses were incubated at either room temperature (lanes $1,3,5$ ) or at the nonpermissive temperature, $29^{\circ} \mathrm{C}$ (lanes $2,4,6$ ). $\mathrm{N}$ proteins coimmunoprecipitated from detergent extracts by anti-Su(H) antibody were detected with the N PCR anti-N antibody. Beneath each lane the ratio of processed $\mathrm{N}$ to $\mathrm{N}$ (termed $\mathrm{N}^{\mathrm{pp} 114} / \mathrm{N}$ ) is shown. The strong temperature-sensitive DI allele (lanes 3,4$)$ has a considerably greater effect on the level of processed $\mathrm{N}$ than the weaker allele (lanes 5,6$)$

We then examined the effect of lowering the level of ligand by using temperature-sensitive mutants of the $\mathrm{N}$ ligand Delta. DI ${ }^{6 \mathrm{~B}} / \mathrm{TM} 6$ (a strong temperature-sensitive $\mathrm{DI}$ allele) and DI ${ }^{\mathrm{RF}} / \mathrm{TM} 6$ (a weak temperature-sensitive $\mathrm{DI}$ al lele) males were mated to DI ${ }^{\mathrm{x}}$ TM 6 (an amorphic DI allele) females. All the embryos from this cross were incubated at either the permissive or nonpermissive temperature. Extracts of these embryos were immunoprecipitated with anti-Su(H) antibody. Figure 3B shows that at the nonpermi ssi ve temperature, temperature-sensitive DI alleles reduce the level of processed compared with full-length $\mathrm{N}$ bound to $\mathrm{Su}(\mathrm{H})$. The ratios of processed to full-length $\mathrm{N}$ obtained by scanning this image are shown beneath each lane. The level of reduction produced by each temperature-sensitive DI all el e appears to correlate with the strength of its mutant phenotype. Incubation of the stronger temperature-sensitive allele, $\mathrm{DI}^{6 \mathrm{~B}}$, at the nonpermissive temperature (Fig. 3, lanes 3,4) reduces the ratio of processed to full-length $\mathrm{N}$ from 1.1 to 0.3 , whereas the weaker allele, $\mathrm{DI}^{\mathrm{RF}}$ (lanes 5,6$)$, only re- duces the ratio from 1.6 to 0.8 . In contrast, in extracts from wild-type embryos, the ratio increases from 2.5 at the permissive to 3.7 at the nonpermissive temperature (lanes 1,2). In extracts of embryos with neurogenic phenotypes produced by expressing antisense m8 RNA or produced by $\mathrm{pcx}^{1}$ parents (Perrimon et al. 1984), there is no decline in the level of processed relative to full-length $\mathrm{N}$ (data not shown).

The above experiments indicate that the presence of $\mathrm{N}^{\text {pp114 }}$ bound to $\mathrm{Su}(\mathrm{H})$ is correlated with $\mathrm{N}$ function and suggest that ligand binding is required for cleavage of $\mathrm{N}$ to generate $\mathrm{N}^{\text {ppl14 }}$ that is bound to $\mathrm{Su}(\mathrm{H})$. However, in converse experiments in which the $\mathrm{N}$ ligand is overexpressed, a more complex picture emerges. In these experiments, heat shock GAL4 was used to induce expression of UAS DI in otherwise wild-type embryos. Two hours after induction of DI, immunoprecipitations with anti- $\mathrm{N}$ antibodies reveal that a $\mathrm{N}$ protein, the size of $\mathrm{N}^{\text {p100B }}$ associated with $\mathrm{Su}(\mathrm{H})$, has become more abundant than in wild-type extracts or in uninduced UAS DI embryos (Fig. 4A; cf. the samples of lanes 1, 3, and 5, which are unphosphatased immunoprecipitations). The increase in abundance of this protein is most obvious when comparing wild-type extracts with extracts from heat shock-induced UAS DI embryos (Fig. 4A, lanes 1, 5). Because of the leakiness of the heat shock promoter, some of this protein can be seen in extracts from uninduced UAS DI embryos (Fig. 4A, lane 3). The mobility of most of the protein produced by UAS DI induction does not change significantly on phosphatase treatment, suggesting little or no phosphorylation (Fig. 4A, lanes 5, 6).

Although ligand binding is required for production of $\mathrm{N}^{\text {pp114 }}$ associated with $\mathrm{Su}(\mathrm{H})$ (see above), the pool of $\mathrm{N}$ protein coimmunoprecipitated by anti-Su(H) on overexpression of the ligand DI did not appear to increase (data not shown), suggesting that most of this DI-induced protein has not become associated with $\mathrm{Su}(\mathrm{H})$. We reasoned that we were more likely to see an increase in processed $\mathrm{N}$ associated with $\mathrm{Su}(\mathrm{H})$ if we induced a tagged form of $\mathrm{N}$ at the same time as DI. In this way, rather than looking for a change superimposed on the steady state level $\mathrm{N}$, we would be looking for a change only in the tagged $\mathrm{N}$ synthesized at the same time as DI. Therefore, we compared the amount of processed $N^{\text {LexA }}$ bound to $\mathrm{Su}(\mathrm{H})$ in extracts of embryos in which $N^{\text {LexA }}$ alone was induced by hairy GAL4 with the amount of processed $N^{\text {LexA }}$ bound to $\mathrm{Su}(\mathrm{H})$ in extracts of embryos in which DI was induced al ong with $\mathrm{N}^{\text {LexA }}$. The results are shown in Figure $4 \mathrm{~B}$. In this experiment, coexpression of $\mathrm{N}^{\text {LexA }}$ with DI results in a $42 \%$ (the phosphatased samples of Fig. 4B, lanes 6,8 ) or $52 \%$ (unphosphatased samples of Fig. 4B, lanes 5,7 ) increase in the level of $\mathrm{N}^{\text {pp114-LexA }}$ associated with $\mathrm{Su}(\mathrm{H})$ when compared with $\mathrm{N}^{\text {LexA }}$ expressed in the absence of additional DI. A histogram summarizing the results of four immunoprecipitations from three protein preparations is shown in Figure 4C. On average, there is a 1.75-fol d increase in the amount of processed compared with full-length $\mathrm{N}$ associated with $\mathrm{Su}(\mathrm{H})$. In addition, as was the case with overexpression of DI in wild-type flies, overexpression of $\mathrm{DI}$ along with $\mathrm{N}^{\text {LexA }}$ results in the pro- 
A

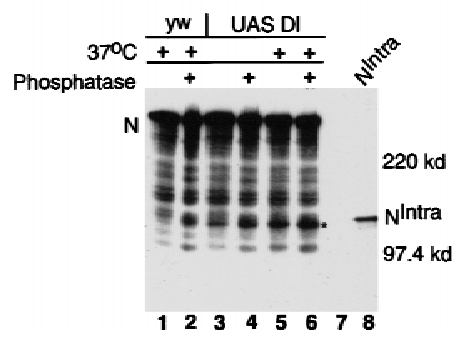

B

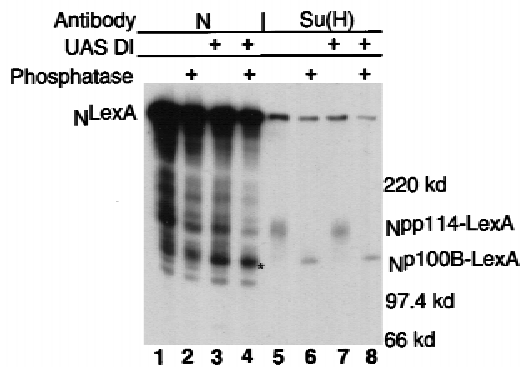

c

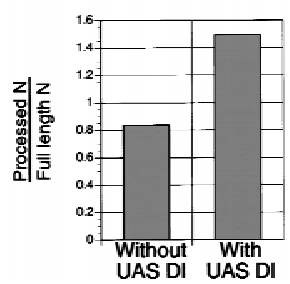

Figure 4. Ligand-induced cleavage of $N$. (A) Anti-N antibodies immunoprecipitate a $\mathrm{N}$ protein, the size of $\mathrm{N}^{\mathrm{p} 100 \mathrm{~B}}(*)$ from embryos exposed to ectopic DI (lane 5). Embryos aged from 2 to $4 \mathrm{hr}$ were heat-shocked at $37^{\circ} \mathrm{C}$ for $30 \mathrm{~min}$ and allowed to recover at $30^{\circ} \mathrm{C}$ for $2 \mathrm{hr}$ prior to detergent extraction. Extracts from either heat-shocked yw (lanes 1,2) or heat-shocked GAL4; U AS DI with (lanes 5,6), or without heat shock (lanes 3,4) were immunoprecipitated with anti-N NI antibody. Lane 7 lacks embryo extract; lane 8 contains $\mathrm{N}^{\text {Intra1768 }}$ in vitro translation products. After immunoprecipitation, lanes marked with a +were treated with alkal ine phosphatase prior to electrophoresis. N proteins were detected with the anti-N antibody N PCR. (Labels) Locations of $N(N)$ and $N^{\text {Intra1768 }}\left(N^{\text {Intra }}\right)$. (B) Coexpression of $N^{\text {LexA }}$ and $D I$ results in an increase in the level of $N^{\text {pp114-LexA }}$. Detergent extracts from 4-8 hr UASN ${ }^{\text {lexA }} \times$ hGAL4 embryos (lanes $1,2,5,6$ ) or UAS DI30B; UAS N ${ }^{\text {lexA }} \times$ hGAL4 embryos (lanes 3,4,7,8) were immunoprecipitated with either anti-N antibody (NI) (lanes 1-4) or anti-Su(H) antibody (lanes 5-8). Samples in lanes 2, 4, 6, and 8 were treated with alkal ine phosphatase prior to electrophoresis. After blotting, proteins were detected with an anti-LexA monoclonal antibody. Coexpression of DI and $\mathrm{N}$ LexA causes the appearance of a novel hypophosphorylated $\mathrm{N}^{\text {LexA }}$ protein in the anti-N immunoprecipitations (*, cf. Ianes 1 and 3$)$. In this experiment, there was an $40 \%-50 \%$ increase in the amount of $N^{\text {pp114-LexA }}$ bound to $\mathrm{Su}(\mathrm{H})$ (cf. the ratios of $\mathrm{N}^{\text {pp114LexA }}$ to $\mathrm{N}^{\text {LexA }}$ in Iane 5 with lane 7, and in lane 6 with lane 8). (C) A histogram comparing the relative amounts of processed vs. full-length $\mathrm{N}$ associated with $\mathrm{Su}(\mathrm{H})$ in the absence or presence of ectopic DI. The average of the results of four immunopreci pitations are plotted. The fold increase in the amount of processed $\mathrm{N}$ compared with full-length $\mathrm{N}$ in the presence of UAS DI for each of the four experiments was as follows: $1.7,1.5,2.0$, and 1.8 .

duction of a hypophosphorylated $\mathrm{N}$ protein the size of $\mathrm{N}^{\mathrm{p} 100 \mathrm{~B}}$ fused to LexA that is immunoprecipitated with anti-N antibody but does not associate with $\mathrm{Su}(\mathrm{H})$ (cf. the unphosphatased samples of Fig. 4B, lanes 1,3).

\section{Intracellular location of the $\mathrm{Su}(\mathrm{H})$ bound $\mathrm{N}$ proteins}

The three dephosphorylated components of $\mathrm{N}^{\mathrm{pp} 114}$ are small enough to be soluble. To see if this was the case, immunoprecipitations were carried out on subcellular fractions of Drosophila embryos. Equal fractions of each subcellular fraction were immunoprecipitated to allow the relative abundance of the proteins in each fraction to be determined. When the fractionation is carried out under hypotonic conditions (10 $\mathrm{mm} \mathrm{KCl}$ ), the majority of $\mathrm{N}$ proteins, full-length as well as $\mathrm{N}^{\text {pp114 }}$, immunoprecipitated by both $\mathrm{N}$ and $\mathrm{Su}(\mathrm{H})$ antibodies are in the membrane fraction (Fig. 5A, lanes $1,2,7,8$ ). Some $N^{p p 114}$ is found in the soluble fraction (Fig. 5A, lanes $3,4,9,10$ ) and little or no $\mathrm{N}$ is detectable in the nuclear fraction (Fig. $5 A$, lanes $5,6,11,12$ ). In addition to $\mathrm{N}^{\text {pp114 }}$, the anti-N immunoprecipitate of the soluble fraction is also enriched for two proteins of $\sim 99 \mathrm{kD}$ and $86 \mathrm{kD}$, which are superimposed over an 86-114 kD smear (Fig. 5, A, lane 3, and $\mathrm{B}$, lane 1). Phosphatase treatment reduces the smear to the hypophosphorylated components of $\mathrm{N}^{\mathrm{pp} 114}$ and a protein of $86 \mathrm{kD}$ (termed $\mathrm{N}^{\mathrm{p} 86}$ ) (Fig. 5, A, lane 4 and $\mathrm{B}$, lane 2) suggesting that $\mathrm{N}^{\mathrm{pp} 99}$ is a phosphorylated form of $\mathrm{N}^{\mathrm{p} 86}$. Despite being soluble, $\mathrm{N}^{\mathrm{pp} 99}$ was not found associated with $\mathrm{Su}(\mathrm{H})$ (Fig. 5A, cf. lanes 3 and 4 with lanes 9 and 10).

In contrast, when subcel lular fractionations are carried out under physiological salt conditions (100 mM KCl) the majority of $\mathrm{N}^{\mathrm{pp} 114}$ associated with $\mathrm{Su}(\mathrm{H})$ is found in the soluble fraction (Fig. 5C, lane 2). Although there is a significant amount of $\mathrm{N}^{\text {pp114 }}$ still found associated with the membrane fraction (Fig. 5C, lane 1), incubation of the post-nuclear supernatant in increasing concentrations of $\mathrm{KCl}$ prior to centrifugation disrupts the association of $\mathrm{N}^{\text {pp114 }}$ with membranes (Fig. 5C, lanes 3,5). These results support the notion that $\mathrm{N}^{\text {pp114 }}$ is the soluble, phosphorylated intracellular domain of $\mathrm{N}$. In conjunction with the results we have presented above, this suggests that on binding its ligand DI, transmembrane $\mathrm{N}$ is cleaved, generating a soluble form that encompasses its cytoplasmic domain, is phosphorylated, and associates with $\mathrm{Su}(\mathrm{H})$.

As well as coimmunoprecipitating $\mathrm{N}^{\mathrm{pp114}}$, anti-Su(H) antibodies also precipitate a $\mathrm{N}$ protein the size of hypophosphorylated $\mathrm{N}^{\mathrm{p} 100 \mathrm{~B}}$ from the membrane fraction (indicated by an asterisk in Fig. 5C). The same salt conditions which disrupted the association of $\mathrm{N}^{\text {pp114 }}$ with membranes do not do so with this protein, suggesting a stronger association with the membrane.

$\mathrm{Su}(\mathrm{H})$ is capable of retaining the cytoplasmic domain of $\mathrm{N}$ in the cytoplasm

The biochemical data presented above suggest that some processed $\mathrm{N}$ complexed with $\mathrm{Su}(\mathrm{H})$ protein is still associated with membranes even though, on the basis of size, it probably lacks a transmembrane domain. In addition, there are larger amounts of $\mathrm{N}$, principally $\mathrm{N}^{\mathrm{pp} 114}$, in the sol uble fraction. This is surprising, as we and others have 
A

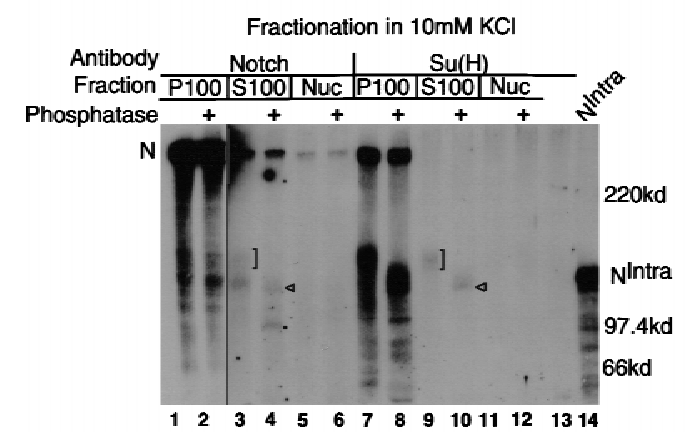

B

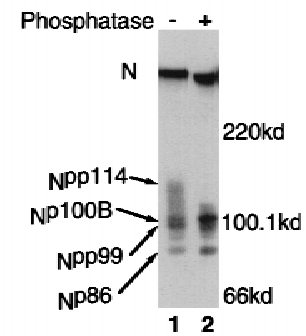

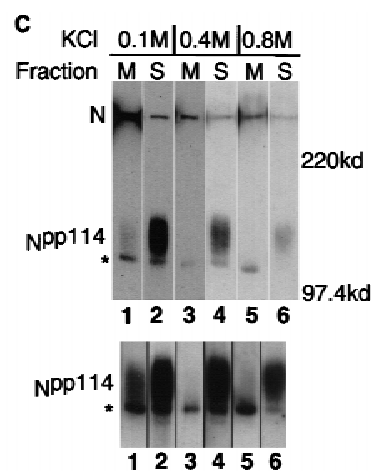

Figure 5. $\mathrm{N}^{\mathrm{pp} 114}$ is a soluble protein. (A) Subcellular distribution of $\mathrm{N}^{\mathrm{pp} 114}$. Subcellular fractions were prepared from Drosophila embryos that had been lysed under hypotonic conditions (10 mM KCl). (N uc) The nuclear fraction; (P100) the membrane fraction; (S100) the soluble fraction. The position of $\mathrm{N}^{\mathrm{pp} 114}$ is indicated by a square bracket, $\mathrm{N}^{\mathrm{p} 100 \mathrm{~B}}$ by an arrowhead, and $\mathrm{N}^{\mathrm{p} 86}$ by a dot. Equal proportions of each fraction were immunoprecipitated with antibodies against either N (NI) (Ianes 1-6) or Su(H) (Ianes 7-12) and then detected with the anti-N PCR antibody. The autoradiograph has been overexposed to show the presence of processed $\mathrm{N}$ in the soluble fraction. Because the amount of $\mathrm{N}$ in the membrane fraction is so high, lanes 1 and 2 are from a shorter exposure. (B) Evidence for additional processing of the cytoplasmic domain of $\mathrm{N}$. Soluble proteins extracted in $0.4 \mathrm{M} \mathrm{KCl}$ were immunoprecipitated with anti-N I antibody and detected with anti-N PCR antibody. As well as immunoprecipitating the same N proteins as those coimmunoprecipitated by anti-Su(H) antibodies, anti- $\mathrm{N}$ antibodies immunoprecipitate two novel proteins of $\sim 99 \mathrm{kD}\left(\mathrm{N}^{\mathrm{pp} 99}\right)$ and $86 \mathrm{kD}\left(\mathrm{N}^{\mathrm{p} 86}\right)(\mathrm{lane} 1)$, treatment with alkaline phosphatase (lane 2) reduces the amount of $N^{p p 99}$ and increases the amount of $N^{\text {p86 }}$, suggesting that $\mathrm{N}^{\text {pp99 }}$ is a phosphorylated form of $\mathrm{N}^{\mathrm{p} 86}$. (C) Some $\mathrm{N}^{\mathrm{pp} 114}$ is associated, but not stably, with membranes. Postnuclear supernatants were incubated with increasing amounts of $\mathrm{KCl}$ prior to fractionation by centrifugation into membrane bound (lanes marked $\mathrm{M}$ ) or soluble proteins (lanes marked S). Fractionated proteins were then immunoprecipitated with anti-Su(H) antibody and detected with the anti-N N PCR antibody, a longer exposure of the relevant region of the resulting autoradiograph is shown at bottom. Some $\mathrm{N}^{\mathrm{pp} 114}$ can be seen to be associated with membranes when extracted at $0.1 \mathrm{M} \mathrm{KCl}$ but is removed at higher salt concentrations. The protein that comigrates with $\mathrm{N}^{\mathrm{p} 100 \mathrm{~B}}$ and appears to be stably associated with membranes is marked by an asterisk.

shown previously that the intracellular domain of $\mathrm{N}$ has functional nuclear localization signals and can localize to nuclei (Stifani et al. 1992; Lieber et al. 1993).

Given our fractionation studies of $\mathrm{N}^{\mathrm{pp} 114}$, subcellular localizations of $N^{\text {Intra }}$ were further examined. Whereas

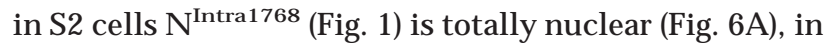
embryos, a substantial fraction of $\mathrm{N}^{\text {Intra1768 }}$ is retained in the cytoplasm. This is illustrated in Figure 6B by use of an anti-Flag-antibody to recognize Flag-tagged $N^{\text {Intra1768. }}$ Using an anti-N antibody, we found that it is in cells in which $N^{\text {Intra1768 }}$ is expressed at higher levels that it is found in nuclei. In cells in which $\mathrm{N}^{\text {Intra1768 }}$ is expressed at lower levels, it is primarily cytoplasmic (Fig. 6C). This suggests that there is something in embryos that is retaining $\mathrm{N}^{\text {Intra1768 }}$ in the cytoplasm, and that this retention mechanism can be saturated by high levels of $\mathrm{N}^{\text {Intra1768 }}$. It has been shown that the cdc10 repeats of $\mathrm{N}$ can mediate homotypic $\mathrm{N}$ interactions (Roehl et al. 1996; M atsuno et al. 1997). However, in embryos that are both maternally and zygotically $\mathrm{N}$ null, there is still substantial cytopl asmic localization of $\mathrm{N}^{\text {intra1768 }}$ (Fig. 6D).

An obvious candidate for a factor influencing subcelIular localization of $\mathrm{N}^{\text {Intra }}$ in the absence of transmembrane $\mathrm{N}$ is $\mathrm{Su}(\mathrm{H})$. In early embryos, $\mathrm{Su}(\mathrm{H})$ is present ubiquitously and local izes to both cytopl asm and nuclei (data not shown). It has been shown in wing discs that $\mathrm{Su}(\mathrm{H})$ is present in the cytoplasm, and that when $\mathrm{N}^{\text {Intra }}$ is expressed to high levels, it is capable of dragging endogenous $\mathrm{Su}(\mathrm{H})$ into nuclei (Gho et al. 1996). Although this is true for high levels of $\mathrm{N}^{\text {Intra1768 }}$ (Fig. 7, Cf. A with B and C), when low levels of $N^{\text {Intra1768 }}$ are coexpressed with
$\mathrm{Su}(\mathrm{H})$ in S2 cells, $\mathrm{N}^{\text {Intra1768 }}$ is retained in the cytoplasm (Fig. 7D-G). Thus, raising the relative level of $\mathrm{Su}(\mathrm{H})$ favors cytoplasmic localization of $\mathrm{N}^{\text {Intra }}$. In accord with this observation, $\mathrm{N}^{\text {Intra1790 }}$ is predominantly nuclear in embryos with reduced levels of Su(H) (Fig. 6E).

The cytoplasmic domain of $\mathrm{N}$ behaves as an activator when bound to DNA

The data we have presented above indicate that $\mathrm{N}$ is processed and associates with $\mathrm{Su}(\mathrm{H})$, and the entry of this complex into the nucleus appears to be dependent on the relative levels of processed $\mathrm{N}$ and $\mathrm{Su}(\mathrm{H})$. During the course of yeast two-hybrid experiments, it was found that the cytopl asmic domain of $\mathrm{N}$ was a strong activator. Figure $8 \mathrm{~A}$ shows a comparison in yeast of the activating ability of the $\mathrm{N}$ cytoplasmic domain with that of the well-characterized transcriptional activator GAL4. It can be seen that the cytoplasmic domain of $\mathrm{N}$ has almost as much activator activity (85\%) as GAL4. Smaller derivatives of the N cytoplasmic domain activate to a lesser degree. Thus, in a heterol ogous system, the cytoplasmic domain of $\mathrm{N}$ strongly activates transcription from a heterologous promoter. This suggests that at least one aspect of $\mathrm{N}$ function could be mediated by its ability to act as a transcriptional transactivator for $\mathrm{Su}(\mathrm{H})$. We tested this in two ways. First, we fused the DNA-binding domain of the bacterial repressor LexA to the cytoplasmic domain of $\mathrm{N}$. In $\mathrm{S} 2$ cells, this $\mathrm{N}^{\text {LexA }}$ fusion protein $\left(\mathrm{N}^{\text {Intra-LexA }}\right.$; Fig. 1$)$, but not $\mathrm{N}^{\text {Intra1790 }}$, activates transcription from a LexA reporter (data not shown). In Fig- 

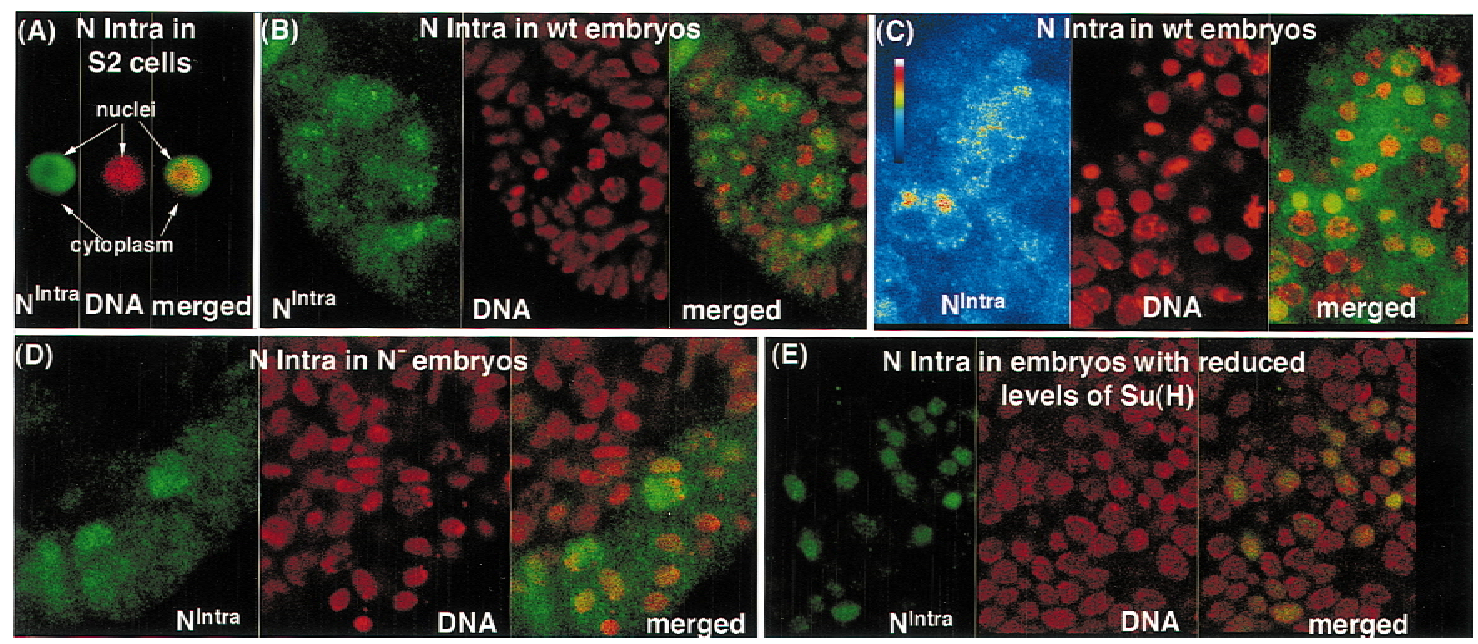

Figure 6. $\mathrm{N}^{\text {Intra }}$ is retained in the cytoplasm in embryos. Confocal images showing the localization of $\mathrm{N}^{\text {Intra }}$ in embryos and Drosophila S2 cells as detected by immunofluorescence. With the exception of the left panel in C, $\mathrm{N}^{\text {Intra }}$ protein is represented in green

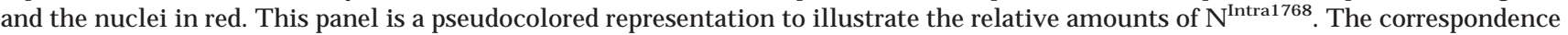
of the colors with the intensity of the signal is indicated by the pseudocolor bar, with the more intense signals being depicted by col ors

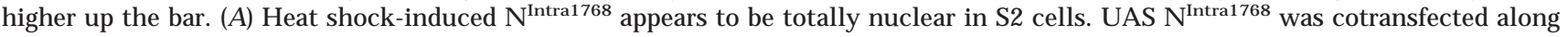
with HS GAL4 and detected with a rabbit anti-N (NI) antibody. The nucleus was detected with SYTOX Green. (B,C) In embryos (hGAL4; U AS $\mathrm{N}^{\text {intra1768}}$ ) there is retention of $\mathrm{N}^{\text {Intra1768 }}$ in the cytoplasm. (B,C, right) The merged images of the $\mathrm{N}$ signal in green and

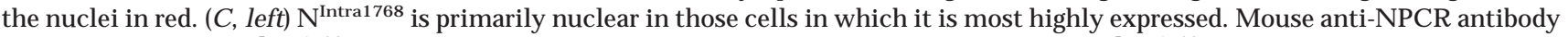
was used to detect $\mathrm{N}^{\text {Intra1768 }}$. (B) Mouse anti-Flag antibody was used to detect Flag-tagged $\mathrm{N}^{\text {Intra1768 }}$. The nuclei were detected by propidium iodide. (D) $\mathrm{N}^{\text {Intra1768 }}$ is still retained in the cytoplasm in embryos that are maternally and zygotically $\mathrm{N}$ null $\left(\mathrm{N}^{264-47}\right.$

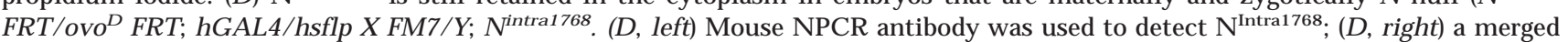

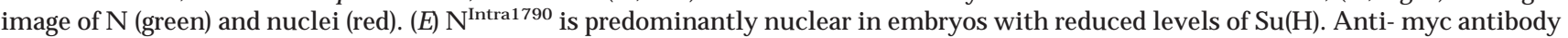
was used to detect myc-tagged $\mathrm{N}^{\text {intra1790 }}$ in embryos that are maternally $\mathrm{Su}(\mathrm{H})^{-}\left(\mathrm{hsflp} / \mathrm{yw} ; \mathrm{Su}(\mathrm{H})^{\mathrm{SF} 8} \mathrm{FRT} / \mathrm{ovo}^{\mathrm{D}}\right.$ FRT; $\mathrm{hGAL4}$ X Su(H)/

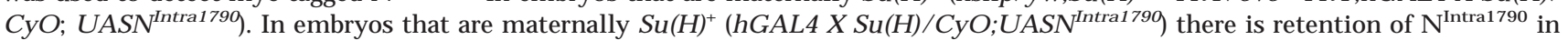
the cytoplasm (data not shown).

ure $8 D$, we show that in embryos, $N^{\text {Intra-LexA }}$ can activate transcription from a LexA- $\beta$-gal actosi dase reporter. The pattern of expression of $\mathrm{N}^{\text {Intra-LexA }}$ is presented in Figure $8 \mathrm{C}$, and coincides well with the pattern of induced $\beta$-galactosidase reporter. Figure $8 \mathrm{~B}$ shows that $N^{\text {Intra1790 }}$ alone, al though expressed in the same pattern as $\mathrm{N}^{\text {Intra-LexA }}$ (data not shown), cannot activate transcription of the LexA reporter. This experiment indicates that in vivo, when $\mathrm{N}$ is directly tethered to DNA, it behaves as a transcriptional activator and suggests that the role of $\mathrm{Su}(\mathrm{H})$ is to guide a transcriptional activator to DNA.

If $\mathrm{N}$ is functioning as a transcriptional transactivator, one would predict that a transcriptional activator directly coupl ed to $\mathrm{Su}(\mathrm{H})$ could substitute for at least some aspects of $\mathrm{N}$ function. To test this, we fused the viral activator VP16 to $\mathrm{Su}(\mathrm{H})$ (Fig. 1). In S2 cells this Su(H)VP16 fusion, but not $\mathrm{Su}(\mathrm{H})$, activates transcription from an $\mathrm{m} 8$ reporter (data not shown). In Figure $8 \mathrm{E}$ we show that this $\mathrm{Su}(\mathrm{H})-\mathrm{VP} 16$ fusion but not $\mathrm{Su}(\mathrm{H})$ (data not shown) can activate $\mathrm{m} 8$ transcription in an embryo that is both maternally and zygotically $\mathrm{N}^{-}$. This experiment demonstrates that a role of $\mathrm{N}$ is to either directly or indirectly provide activator function to $\mathrm{Su}(\mathrm{H})$.

\section{Discussion}

Previous work has led to the model that on ligand bind- ing, $\mathrm{N}$ is cleaved, and the cytoplasmic domain enters the nucleus where, in concert with $\mathrm{Su}(\mathrm{H})$, it activates transcription of genes such as m8, a member of the $\mathrm{E}(\mathrm{spl})$ complex (Lieber et al . 1993; Jarriault et al. 1995; Kopan et al. 1996; Lecourtois and Schweisguth 1998; Schroeter et al. 1998; Struhl and Adachi 1998). In this study, it has been shown that (1) soluble cytoplasmic N proteins are produced in vivo in response to the N ligand, DI (2) Su(H) is recovered in association with these soluble forms of $\mathrm{N}$, and (3) intracellular forms of $\mathrm{N}$ appear to function as transcriptional activators in embryos when physically associated with $\mathrm{Su}(\mathrm{H})$.

We have used antibodies against $\mathrm{Su}(\mathrm{H})$ and $\mathrm{N}$ to examine the structure of the $N$ proteins associated with $\mathrm{Su}(\mathrm{H})$. During most of Drosophila embryogenesis, two size classes of $\mathrm{N}$ proteins are coimmunoprecipitated by antibodies against $\mathrm{Su}(\mathrm{H})$. These include full-length $\mathrm{N}$ proteins and, to a greater extent, phosphoproteins of $\sim 114$ $\mathrm{kD}, \mathrm{N}^{\mathrm{pp} 114}$. Unlike mammalian systems in which $\mathrm{N}$ exists predominantly as a heterodimer, during Drosophila embryogenesis, the bulk of $\mathrm{N}$ exists as the full-length form (Results; Kidd et al. 1989; Blaumueller et al. 1997). When dephosphorylated, $\mathrm{N}^{\text {pp114 }}$ resolves into three proteins, $\mathrm{N}^{\mathrm{p} 100 \mathrm{~A}}, \mathrm{~N}^{\mathrm{p} 100 \mathrm{~B}}$, and $\mathrm{N}^{\mathrm{p} 100 \mathrm{C}}$ of $\sim 100 \mathrm{kD}$. Through most of embryogenesis, the most abundant of these proteins is $\mathrm{N}^{\mathrm{p} 100 \mathrm{~B}}, \mathrm{~N}^{\mathrm{p} 100 \mathrm{C}}$ being found only late in development. The size difference between the two proteins might be because $\mathrm{N}^{\mathrm{p} 100 \mathrm{C}}$ has been cleaved further into 

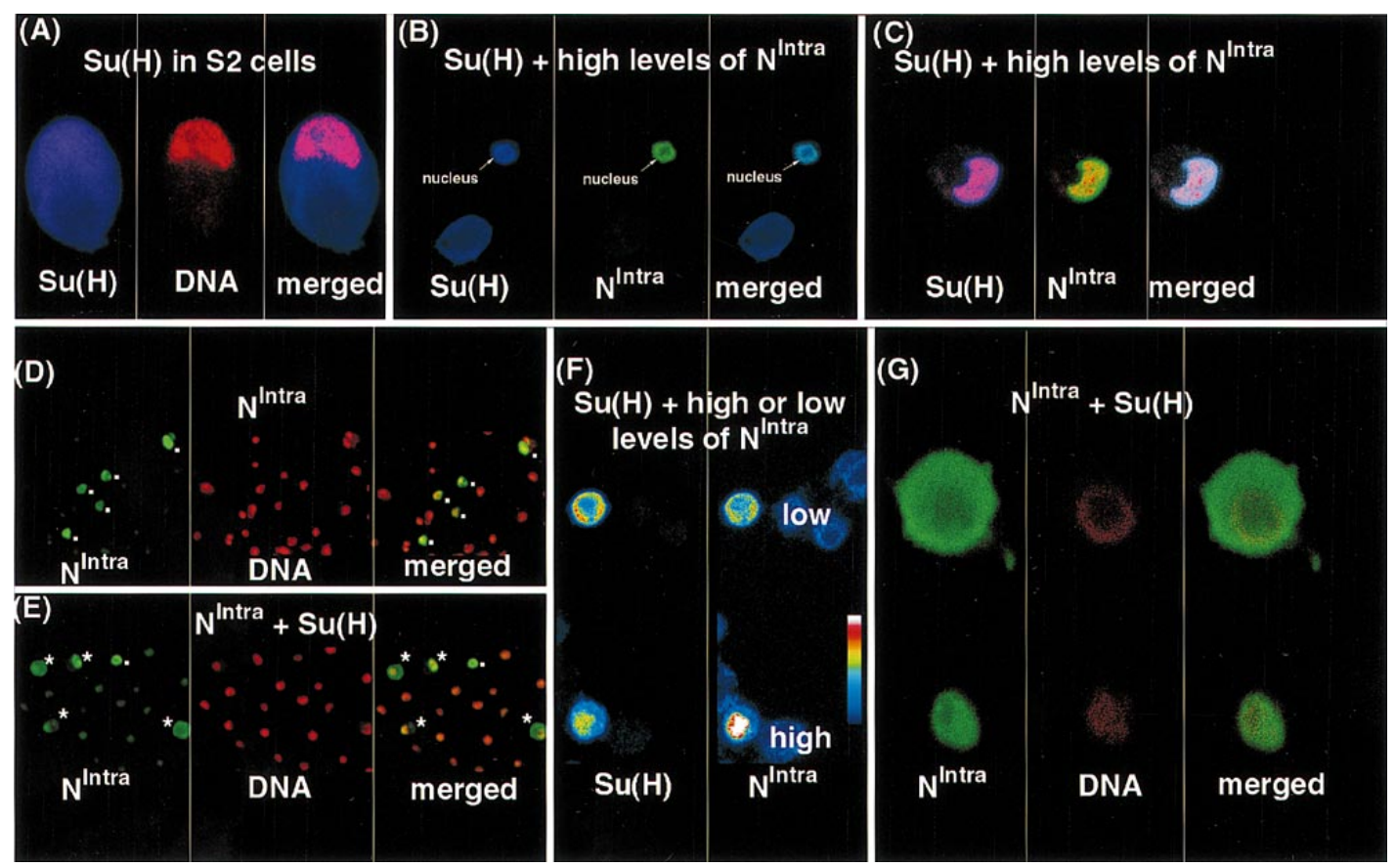

Figure 7. $\mathrm{Su}(\mathrm{H})$ can retain $N^{\text {Intra }}$ in the cytoplasm. Confocal images showing the localization of $\mathrm{Su}(\mathrm{H})$ and $N^{\operatorname{lntra1768}}$. With the exception of $\mathrm{F}$, which is a pseudocolored image, $\mathrm{Su}(\mathrm{H})$ is represented in blue, $\mathrm{N}^{\text {Intra }}$ in green, and the nuclei in red. $(A) \mathrm{Su}(\mathrm{H})$ is expressed in both the cytoplasm and nuclei of transfected S2 cells. S2 cells were transfected with a construct expressing Su(H) under the control of an actin promoter. $\mathrm{Su}(\mathrm{H})$ is detected with rat anti-Su(H) antibody and the DN A with SYTOX Green. (B,C) Coexpression of high levels of $\mathrm{N}^{\text {intra1768 }}$ along with $\mathrm{Su}(\mathrm{H})$ results in both being found in nuclei of S2 cells. (B) Two cells are depicted showing Su(H) expression in blue and $\mathrm{N}$ expression in green. In the lower cell, no $\mathrm{N}^{\text {Intra1768 }}$ is present and $\mathrm{Su}(\mathrm{H})$ is localized ubiquitously. In contrast, the upper cell expresses high levels of $\mathrm{N}^{\text {Intra1768 }}$ al ong with $\mathrm{Su}(\mathrm{H})$ and both are localized in the nucleus. A merged image of the first two panels is shown at right. The cell shown in $\mathrm{C}$ was probed with a DN A marker as well as with anti-N and Su(H) antibodies. Actin driven $\mathrm{Su}(\mathrm{H})$ was cotransfected with UAS N ${ }^{\text {Intral768 }}$ and HS GAL4. Su(H) protein was detected by rat anti-Su(H) antibody, N protein was detected by a mouse anti-Flag antibody, and the DNA with SYTOX Green. (D,E,G) The difference in Iocalization of ${ }^{\text {Intral768 }}$ promoted by expression of an excess of $\mathrm{Su}(\mathrm{H}) . \mathrm{N}^{\text {Intra }}$ is represented in green and the nuclei in red. (D) UAS N ${ }^{\text {Intra1768 }}$ and HS GAL4 were transfected into S2 cells. (E,G) A $20 \times$ mass excess of actin Su(H) was cotransfected al ong with UAS N ${ }^{\text {Intra1768 }}$ and HS GAL4. (D,E)

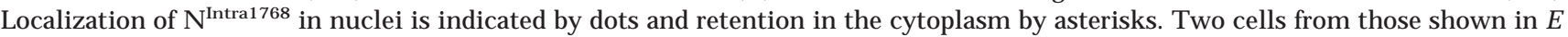
are depicted at higher magnification in G. As cytoplasmic localization of $N^{\text {Intral768 }}$ is never seen in cells lacking ectopic Su(H) (D), the upper cell in $\mathrm{G}$ must have received more $\mathrm{Su}(\mathrm{H})$ relative to $\mathrm{N}^{\text {Intra1768 }}$ than the lower one, resulting in $\mathrm{N}^{\text {Intra1768 }}$ being retained in the cytoplasm. $\mathrm{N}^{\text {Intra1768 }}$ was detected with a rabbit anti-N (NI) antibody and the nuclei with SYTOX Green. (F) When low levels of

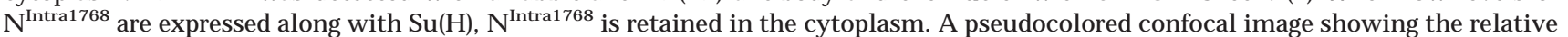
levels on $\mathrm{N}$ at right and $\mathrm{Su}(\mathrm{H})$ at left is portrayed. The intensity of staining is depicted by the pseudocolor bar with the colors representing the more intensely stained regions being higher up the bar. In the lower cell, $\mathrm{N}^{\text {Intra1768 }}$ is expressed at relatively high levels and both $\mathrm{N}^{\text {Intra1768 }}$ and $\mathrm{Su}(\mathrm{H})$ are found in the nucleus. In the upper cell, $\mathrm{N}^{\text {Intra1768 }}$ is expressed at relatively low levels and both

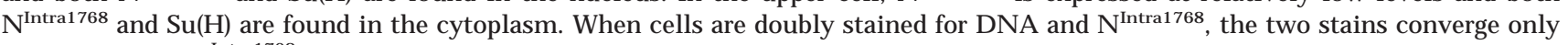
when levels of $N^{\text {Intra1768 }}$ are high compared with $\mathrm{Su}(\mathrm{H})$ (data not shown). Su(H) was detected with a rat anti-Su(H) antibody and $\mathrm{N}^{\text {Intra1768 }}$ with a mouse anti-Flag antibody.

the intracel lular domain than $\mathrm{N}^{\mathrm{p100B}}$, or the two proteins may both have the same amino termini, but $\mathrm{N}^{\text {p100C }}$ might have been additionally cleaved at the carboxyl terminus. It is al so possi ble that there is a precursor product relationship between the two. In any case, the occurrence of $\mathrm{N}^{\text {p100C }}$ only late in embryogenesis suggests that production of these forms of $\mathrm{N}$ is under developmental control.

Throughout most of embryogenesis, the majority of processed $\mathrm{N}$ proteins that are associated with $\mathrm{Su}(\mathrm{H})$ show some level of phosphorylation. Full-length $\mathrm{N}$ has been shown previously to be phosphorylated on serines (Kidd et al. 1989). We do not know how the latter relates to the phosphorylation described here, al though the pres- ence of hypophosphorylated forms of $\mathrm{N}$ bound to $\mathrm{Su}(\mathrm{H})$ suggests that the two events are unrelated. How this phosphorylation is effected and how it influences $\mathrm{N}$ function is not known. There are two lines of evidence that suggest that phosphorylation is not an immediate consequence of ligand binding and cleavage. First, most

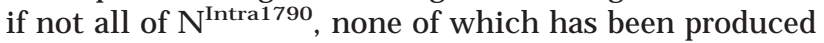
as a result of ligand binding and cleavage of $\mathrm{N}$, is phosphorylated (Fig. 2C). Second, overexpression of DI induces at least one processed form of $\mathrm{N}$ which is hypophosphorylated (Fig. 4). In addition, we have shown that phosphorylation of $\mathrm{N}^{\text {Intra1790 }}$ is not dependent on the presence of $\mathrm{Su}(\mathrm{H})$ (Fig. 2C). Because most, if not all, of $\mathrm{N}^{\text {Intra1790 }}$ is phosphorylated and there is an enrichment 


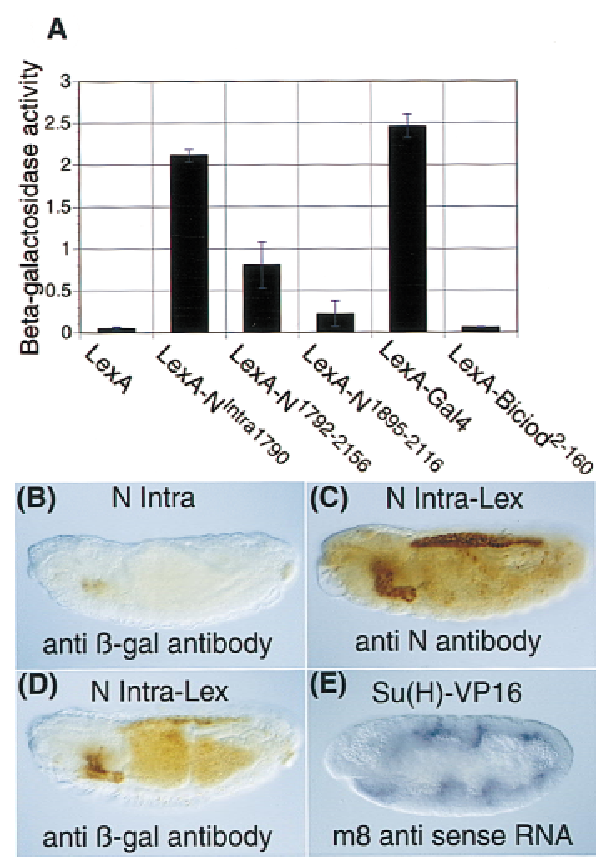

Figure 8. The cytoplasmic domain of $\mathrm{N}$ can behave as a transcriptional activator. (A) The cytoplasmic domain of $\mathrm{N}$ is a transcriptional activator in yeast. The transcriptional activation activity of various $\mathrm{N}$ constructs fused to the DN A-binding domain of LexA (Fig. 1) was determined by their ability to drive expression from a LexA- $\beta$-galactosidase reporter. The bar marked LexA is the $\beta$-galactosidase activity of yeast expressing the vector al one, LexA-Bicoid ${ }^{2-160}$ is a negative control. The height of the bar is the average of three samples, standard deviations are shown by the error bars. (B) $N^{\text {Intra1790 }}$ cannot activate transcription from LexA- $\beta$-galactosidase reporter. A lexA- $\beta$-gal; UAS $N^{\text {intra1790; }}$ HS GAL4 embryo is stained with anti $\beta$-galactosi dase antibody. There is anti $\beta$-galactosidase reactivity in the secretory cells and the anal pads that results from leakiness of the reporter. (C) $\mathrm{N}^{\text {Intra1790-LexA }}$ accumulates to its highest levels in the salivary glands, amnioserosa, and midgut. A lexA- $\beta$-gal;

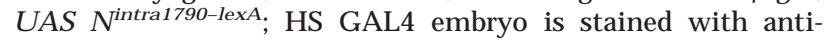
NPCR antibody. (D) $N^{\text {Intra1790-LexA }}$ induces expression of $\beta$-gal from the LexA- $\beta$-gal reporter. A lexA- $\beta$-gal; UAS $N^{\text {intra1790-LexA }} ;$ HS GAL4 embryo is stained with anti $\beta$-galactosidase antibody. $\beta$-Galactosidase accumulates in the salivary glands, amnioserosa and midgut, which correspond with regions that accumulate the highest levels of $\mathrm{N}^{\text {Intra1790-LexA }}$ in $C$. $(B, C, D)$ Embryos were fixed $2 \mathrm{hr}$ after a 30-min heat shock. (E) A heterologous activator fused to $\mathrm{Su}(\mathrm{H})$ can substitute for $\mathrm{N}$ function and activate transcription of m8. $\mathrm{N}^{264-47} \mathrm{FRT} / \mathrm{ovo}^{\mathrm{D}}$ FRT; h GAL4/hsflp ×FM 7 lac-Z/Y; myc Su(H)-VP16 embryos are stained with an $m 8$ probe. $m 8$ expression is induced in seven stripes, in which $\mathrm{h}$ is expressed. Overexpression of $\mathrm{Su}(\mathrm{H})$ al one does not result in induction of $\mathrm{m} 8$ expression (data not shown). Anti $\beta$-galactosidase antibody was used to distinguish the $\mathrm{N}$ null embryos.

of $\mathrm{N}^{\mathrm{pp} 114}$ in the soluble fraction (Fig. 5), perhaps phosphorylation is related to the release of cleaved intracelIular $\mathrm{N}$ from the membrane. Alternatively, phosphoryIation may promote nucl ear translocation or association with $\mathrm{Su}(\mathrm{H})$, or both.

There is some salt extractable $\mathrm{N}^{\text {pp114 }}$ associated with
$\mathrm{Su}(\mathrm{H})$ in the membrane fraction. Finding the intracellular domain of $\mathrm{N}$, which contains functional nuclear local izati on signals either in the membrane or cytoplasmic fractions, indicates that the cell contains mechanisms to restrain the nuclear entry of $\mathrm{N}$ cleavage products. Because it has been demonstrated that the cdc10 repeats of $\mathrm{N}$ mediate homodimerization (Matsuno et al. 1995; Roehl et al. 1996), newly produced intracellular forms of $\mathrm{N}$ may be retained by full-length forms of $\mathrm{N}$ at the membrane. This association might be particularly favored if, as believed, the receptor is presented at the cell surface as a dimer (Foster 1975; Portin 1975; Kelley et al. 1987; de Celis and Garcia-Bellido 1994). It is also conceivable that $\mathrm{N}^{\text {pp114 }}$ is retained on the membrane by a compl ex of $\mathrm{Su}(\mathrm{H})$ and full-length $\mathrm{N}$.

\section{$\mathrm{Su}(\mathrm{H})$ may regulate nuclear entry of $\mathrm{N}$}

With respect to cytoplasmic retention of $\mathrm{Su}(\mathrm{H}) / \mathrm{N}^{\mathrm{pp} 114}$ complexes, regulation may come from $\mathrm{Su}(\mathrm{H})$ itself. We have shown that whereas coexpressing high levels of $\mathrm{N}^{\text {Intra }}$ along with $\mathrm{Su}(\mathrm{H})$ in $\mathrm{S} 2$ cells results in both proteins translocating to nuclei, when low levels of $\mathrm{N}^{\text {intra }}$ are coexpressed along with $\mathrm{Su}(\mathrm{H})$ in $\mathrm{S} 2$ cells, there is retention of $\mathrm{N}^{\text {Intra }}$ in the cytoplasm. This suggests that excess $\mathrm{Su}(\mathrm{H})$ can promote cytoplasmic localization of soluble, intracellular forms of N. Given that there are multiple binding sites for $\mathrm{Su}(\mathrm{H})$ in the cytoplasmic domain of $\mathrm{N}$ (Kato et al. 1997; Wettstein et al. 1997; S. Kidd, unpubl.), differences in subcellular Iocalization could reflect the number of $\mathrm{Su}(\mathrm{H})$ mol ecules bound to $\mathrm{N}$, with changes in stoichiometry resulting from increased levels of intracellular $\mathrm{N}$ in response to ligand. Because in vivo levels of $\mathrm{Su}(\mathrm{H})$ appear to be in excess to soluble $\mathrm{N}$ product, as there is sufficient $\mathrm{Su}(\mathrm{H})$ to bind to ectopi cally expressed $\mathrm{N}^{\text {Intra }}$ and generate gain of function phenotypes (Lieber et al. 1993; Rebay et al. 1993; Struhl et al. 1993), the cytoplasmic retention we observe in $\mathrm{Su}(\mathrm{H})^{+}$ embryos is expected from the S2 cell studies. Further supporting our view that $\mathrm{Su}(\mathrm{H})$ can retain soluble $\mathrm{N}$ in the cytoplasm in vivo, we found that lowering the dose of $\mathrm{Su}(\mathrm{H})$ promotes nuclear localization of $\mathrm{N}^{\text {Intra }}$ in embryos (Fig. 6E). We also find that lowering the dose of $\mathrm{Su}(\mathrm{H})$ increases the severity of the phenotype produced by ectopic expression of gain-of-function $\mathrm{N}$ proteins in transgenic flies: Whereas complete loss of $\mathrm{Su}(\mathrm{H})$ abolishes the ability of the $\mathrm{E}(\mathrm{spl})$ complex to respond to activated N (Bailey and Posakony 1995), lowering the $\mathrm{Su}(\mathrm{H})$ dose by one-hal $\mathrm{f}$ increases the lethality as well as the bristle loss observed in transgenic flies carrying $\mathrm{N}^{\Delta \mathrm{LN} \text { rpts }}$ under control of a heat shock promoter ( $\mathrm{T}$. Lieber, unpubl.). A priori, one would have predicted that lowering the dose of a downstream component in the $\mathrm{N}$ pathway would decrease the severity of gain-of-function $\mathrm{N}$ mutations. Lastly, it is possible that the subcellular distribution of $\mathrm{Su}(\mathrm{H}) / \mathrm{N}^{\text {pp114 }}$ complexes is regulated by interaction with additional factors. For example, it has been shown that numb, a membrane-associated protein that is asymmetrically localized during division of sensory organ precursor cells in the peripheral nervous sys- 
tem, is able to retain $\mathrm{N}^{\text {Intra }}$ at the membrane and in the cytoplasm of S2 cells (Frise et al. 1996).

In the absence of $\mathrm{Su}(\mathrm{H})$, both $\mathrm{N}^{\text {Intra }}$ and $\mathrm{N}$ appear to have undergone additional modification. In addition, many intermediately sized $\mathrm{N}$ proteins are missing (Fig. 2C). Lecourtois and Schwei sguth, (1998) and Schroeter et al. (1998) have suggested that the processed form of $\mathrm{N}$ is less stable in the absence of $\mathrm{Su}(\mathrm{H})$. M any proteins are targeted to the proteosome by ubiquitinylation. Perhaps the modification of $\mathrm{N}^{\text {Intra }}$ and $\mathrm{N}$ we see in the absence of $\mathrm{Su}(\mathrm{H})$ is ubiquiti nylation. Interestingly, phosphorylation has also been shown to target proteins to the ubiquitinylation machinery (King et al. 1996).

In addition to being required for the production of $\mathrm{N}^{\mathrm{pp} 114}$, the $\mathrm{N}$ ligand $\mathrm{DI}$, when overexpressed, promotes accumulation of a hypophosphorylated $\mathrm{N}$ protein that has approximately the same mobility as $\mathrm{N}^{\text {p100B }}$ (Fig. 4A). Our fractionation studies al so showed the presence of a hypophosphorylated protein of approximately the same size as $\mathrm{N}^{\mathrm{p} 100 \mathrm{~B}}$, in this case associated with $\mathrm{Su}(\mathrm{H})$. This protein is retained in the membrane fraction under salt conditions that remove $\mathrm{N}^{\text {pp114 }}$, suggesting that it is tightly associated with the membrane and may well span it (Fig. 5C). The extracellular domain of $\mathrm{N}$ has been shown previously to be cleaved at several positions (Blaumueller and Artavanis-T sakonas 1997; Pan and Rubin 1997; Logeat et al. 1998). It has been proposed that the cleavage closest to the membrane is ligand dependent (Logeat et al. 1998). Such a cleavage product may correspond to the protein we described above.

\section{Soluble $\mathrm{N}$ as a transcriptional transactivator}

The work of Lecourtois and Schweisguth (1997) and Struhl and Adachi (1998) has shown genetically that the cytoplasmic domain of $\mathrm{N}$ has access to the nucleus. The most likely explanation for their results is that Drosophila $\mathrm{N}$ is proteolytically cleaved at the site described by Schroeter et al. (1998) to produce the fragment of $N$, $\mathrm{N}^{\mathrm{pp} 114}$, that we have described in this paper. We have shown that when tethered directly to DNA via a bacterial DNA-binding domain, the cytoplasmic domain of $\mathrm{N}$ can activate transcription both in yeast and in vivo. Conversely, a viral activator fused to $\mathrm{Su}(\mathrm{H})$ can substitute for the functions of $\mathrm{N}$ mediated by its ability to activate transcription of $\mathrm{m} 8$, a natural target of $\mathrm{N}$ signaling, in embryos. Whereas maximal activation in yeast is seen with the entire cytoplasmic domain, in agreement with the results of Roehl et al. (1996) a truncated form of the cytoplasmic domain ( ${ }^{1792-2156} ;$ Fig. 1) encompassing the cdc10 repeats does weakly activate and has a gainof-function phenotype in embryos (T. Lieber, unpubl.). Smaller versions of the cytoplasmic domain ( ${ }^{1895-2156}$ ) spanning just the cdc10 repeats are even weaker activators and when expressed in wild-type embryos do not have a gain-of-function phenotype (T. Lieber, unpubl.). Our data suggest that the prime function of the sequences downstream of the cdc10 repeats is to provide transactivator activity. In accord with this, the cytoplasmic domain of $\mathrm{N}$ has many features that are found in transcriptional activators (Lieber et al. 1993). Although it is possible that $\mathrm{N}$ indirectly confers activating ability on $\mathrm{Su}(\mathrm{H})$, given the finding of appropriately processed $\mathrm{N}$ proteins, which contain functional nuclear localization signal s preferentially associated with $\mathrm{Su}(\mathrm{H})$, the simplest interpretation of our results is that one function of $\mathrm{N}$ is to bind to $\mathrm{Su}(\mathrm{H})$ and in the nucleus to directly act as its transcriptional transactivator. Recently it has been suggested that $\mathrm{N}$ activates transcription by disrupting the formation of a repressor complex between $\mathrm{Su}(\mathrm{H})$ and a histone deacetylase complex (SMRT/HDAC-1) (Kao et al. 1998). Our data suggest that rather than simply disrupting the $\mathrm{Su}(\mathrm{H}) / \mathrm{SMRT} / \mathrm{HDAC}-1$ complex, $\mathrm{N}^{\mathrm{pp} 114}$ plays a more active role of providing transactivator activity to $\mathrm{Su}(\mathrm{H})$.

One other class of membrane-bound transcription factors has been identified previously. The proteolysis of sterol regulatory element binding proteins (SREBPs) (for review, see Brown and Goldstein 1997) is regulated by sterols that accumulate in membranes. As $\mathrm{N}$ like molecules have been found in all multicellular organisms where they have been sought, $\mathrm{N}$ is an evolutionarily old protein. The existence of a transcription factor that spans the membrane with an extracellular domain capable of interacting with ligands and an intracellular domain that can enter nuclei and activate transcription would provide a simple means for transducing information from neighboring cells. Possibly, the only additional components required would be a protease capable of recognizing a conformational change induced in $\mathrm{N}$ on ligand binding resulting in its cleavage, and a second protease that would degrade the cytoplasmic domain in nuclei so that the signaling could be terminated.

\section{Establishing a threshold for Notch signaling}

The binary epidermal versus neural cell fate choice me diated by the $\mathrm{N}$ signaling pathway involves regulating groups of initially equivalent cells that express both ligand and receptor. Schroeter et al. (1998) have shown that in vertebrate cell culture, extremely low levels of nuclear $\mathrm{N}$ are sufficient for function, and our studies of the wild-type Drosophila embryo are consistent with this finding in that no $\mathrm{N}$ is detected in the nucleus either biochemically or by immunofluorescence. However, relatively abundant cleaved $\mathrm{N}$ associated with $\mathrm{Su}(\mathrm{H})$ is detected in the cytoplasm. Why should there be such a disparity between levels of soluble $\mathrm{N}$ in the cytoplasm and nucleus, and why shouldn't such a potent nuclear N signal favor saltatory cell fate decisions, with all cells composing an equival ence group assuming the same secondary cell fate? U niform expression of Ii gand and receptor among interacting cells might also be expected to favor a saltatory response.

Some of the puzzling aspects of $\mathrm{N}$ signaling are reminiscent of ultrasensitive systems such as the Xenopus oocyte system described by Ferrell and M achleder (1998), in which a continuously variable signal, progesterone, is converted into an all-or-none response, oocyte maturation. An ultrasensitive system exhi bits little response to 
Iow levels of stimulus but switches from off to on over a narrow range of stimulus concentration. We suggest that the cytoplasmic retenti on of $\mathrm{N}^{\mathrm{pp} 114} / \mathrm{Su}(\mathrm{H})$ complexes described in the present study may similarly reflect a mechanism in which the response to low levels of signal is damped. In such a model for $\mathrm{N}$ signaling, only high levels of signal result in sufficient cytoplasmic accumulation of $\mathrm{N}^{\mathrm{pp114}} / \mathrm{Su}(\mathrm{H})$ complex to permit its nuclear entry.

In the Xenopus oocyte system, added ultrasensitivity is provided by a positive feedback loop. Earlier genetic studies have suggested that small differences in the expression of $\mathrm{N}$ and $\mathrm{DI}$ may also be amplified by positive feedback to generate robust intercellular differences in the expression of these proteins among cells derived from an equivalence group (Seydoux and Greenwald 1989; Heitzler and Simpson 1991; for review, see Greenwald 1998). By affecting the nuclear entry of $\mathrm{N} / \mathrm{Su}(\mathrm{H})$ complex, which functions as a transcriptional activator, $\mathrm{Su}(\mathrm{H})$ would also be an element of such a feedback mechanism. We suggest that the $\mathrm{N}$ signal is initiated and maintained according to the relative amounts of $\mathrm{N}, \mathrm{DI}$, and $\mathrm{Su}(\mathrm{H})$. Together, these would determine the rate and duration of accumulation of $\mathrm{N} / \mathrm{Su}(\mathrm{H})$ complex and the threshold at which it enters the nucleus.

\section{Materials and methods}

\section{Constructs}

$\mathrm{N}^{\text {Intra1768 }}$ was expressed by cloning into a derivative of pUAST (Brand and Perrimon 1993) which contains the cactus initiation codon fused to a Flag epitope (Kidd 1992). To express the cytoplasmic domain of $\mathrm{N}$ by coupled in vitro transcription/ translation (Promega), a derivative of $\mathrm{N}^{\text {Intra1768 }}$ was made in which the region containing the last three introns of $\mathrm{N}$ was replaced with the corresponding segment of CDNA. $\mathrm{N}^{\text {intra1790 }}$ contains the first two amino acids of cactus followed by a 14 amino acid myc epitope (Xu and Rubin 1993), which was then fused to amino acid 1790 of $\mathrm{N}$. The hsN ${ }^{\text {Intra }} 1790$ used in Fig. 2C is $\mathrm{N}^{\text {Intracellular domain }}$ (Lieber et al. 1993).

$\mathrm{N}^{\text {LexA }}$ has amino acids 1-87 of LexA fused to the carboxyl terminus of $N . N^{\triangle E G F 1-36-L e x A}$ is a derivative of the above lacking the 36 EGF repeats. $N^{\text {Intral790-LexA }}$ has amino acids 1-87 of LexA fused to the carboxyl terminus of $N^{\text {Intra1790 }}$. The LexA- $\beta$ gal actosi dase, reporter has eight LexA operator sites (Ebina et al. 1983) upstream of a heat shock minimal promoter. This was then inserted in place of the GAL4-UAS region of pUAST (Brand and Perrimon 1993).

M yc-tagged $\mathrm{Su}(\mathrm{H})$ contains the first two amino acids of cactus followed by a 14 amino acid myc epitope that was then fused to amino acid 10 of $\mathrm{Su}(\mathrm{H})$ (Schweisguth and Posakony 1992). M yctagged Su(H)-VP16 has amino acids 19-105 of VP16 (Campbell et al. 1984) fused to the carboxyl terminus of myc Su(H).

With the exception of LexA- $\beta$-gal, all constructs were subcloned into pUAST (Brand and Perrimon 1993) for transformation into flies.

Y east expression experiments were carried out as described by (Gyuris et al. 1993).

\section{Fly stocks}

The following fly stocks, w ovoD1 FRT101; hsFLP, yw FRT101
(Chou et al. 1993), hsFLP12; Sco/Cyo, ovoD1 FRT40A/Cyo (Chou and Perrimon 1996), h-GAL4, hs-GAL4 (Brand and Perrimon 1993) were obtai ned from A. Brand and N. Perrimon; Su(H) (FlyBase 1998) was obtained from the Bloomington Stock Center; Su(H) SF8 FRT40A/CyO (Schweisguth and Posakony 1994) was obtained from F. Schweisguth; $\mathrm{DI}^{6 \mathrm{~B}}$ and $\mathrm{DI} \mathrm{RF}^{\mathrm{RF}}$ (Parks and Muskavitch 1993) were obtained from M. Muskavitch, UASDI, (Doherty et al. 1996) was obtained from Y. Jan. $\mathrm{N}^{264-47}$ and DI ${ }^{\times}$are described by (FlyBase 1998).

\section{Antibodies}

Antibodies were raised against histidine-tagged $\mathrm{Su}(\mathrm{H})$ as previously described (Kidd et al. 1986; Lieber et al. 1993). The remaining $\mathrm{N}$ antibodies (shown in Fig. 1) have been described previously (Lieber et al. 1993). Anti-LexA monoclonal antibody was from Clonetech. M 5 anti-Flag antibody was from Kodak. c-M yc antibody was from Calbiochem. SYTOX Green used to label S2 cell nuclei was from Molecular Probes. Immunocytochemistry and immunofluorescence was as described previously (Lieber et al. 1993). Double labeling with RN A and antibody was as described by Azpiazu and Frasch (1993).

\section{Immunoprecipitations}

Embryo extractions and immunopreciptations were essentially as described by Kidd (1992). Between $300 \mu \mathrm{g}$ and $1 \mathrm{mg}$ of protein were used for immunoprecipitation with anti-Su(H) antibodies, one-fifth of this amount was used with anti-N antibodies. Immunoprecipitions were carried out overnight with protein A-Sepharose and Gamma Bind (Pharmacia) to collect rabbit and rat and mouse antibodies, respectively. After washing, the immunoprecipitates were treated with alkaline phosphatase (Boehringer M annheim) as described previously (Kidd 1992) and electrophoresed without further washes. After blotting, $\mathrm{N}$ in rabbit anti-N and rat anti-Su(H) immunoprecipitates was detected with mouse anti-N, Su(H) in mouse anti-N immunoprecipitates was detected with rat anti-Su(H). Horseradish peroxidase (HRP) conjugated secondary anti bodies were from Jackson. HRP activity was detected by the ECL system (Amersham).

Scanned autoradiographs were quantitated on a Macintosh computer with the public domain NIH Image program (developed at the U.S. $\mathrm{N}$ ational Institutes of $\mathrm{Health}$ and available on the Internet at http://rsb.info.nih.gov/nih-image).

Two procedures were used to produce subcellular fractions of embryos. The first, used for Figure 5A, was based on procedures for producing extracts for gel shifts (Andrews and Faller 1991). The second procedure, used for Figure 5, B and C, was as follows: Dechorionated embryos were extensively homogenized in $10 \mathrm{~mm}$ HEPES (pH 7.6), $100 \mathrm{~mm} \mathrm{KCl,} 50 \mathrm{~mm} \mathrm{NaF}, 2$ mm EDTA, $2 \mathrm{~mm}$ EGTA, and $2 \mathrm{~mm}$ ammonium molybdate with protease inhibitors. After centrifuging the homogenate at $900 \mathrm{~g}$ for $5 \mathrm{~min}$, the resulting postnuclear supernatant was incubated on ice for 20 min either with no additional salt or an additional 0.4 or 0.8 $\mathrm{M} \mathrm{KCl}$, and then centrifuged for $2 \mathrm{hr}$ at $100,000 \mathrm{~g}$. The supernatants were adjusted to $0.5 \%$ Triton $X-100$ and to $\sim 400 \mathrm{mM} \mathrm{KCl}$, and the pellets resuspended in the Triton lysis solution prior to immunoprecipitations.

\section{Acknowledgments}

We thank A. Brand, N. Perrimon, M. Muskavitch, F. Schweisguth, and Y. Jan for fly stocks, F. Schweisguth, and K. N akao for DN As, Krishna Patel, M arla A bodeely, and Y vonne DeLotto for 
excellent technical assistance, and reviewers for insightful comments. This work was supported by $\mathrm{N}$ ational Institutes of Health grant GM 25103 to M.W.Y.

The publication costs of this article were defrayed in part by payment of page charges. This article must therefore be hereby marked 'advertisement' in accordance with 18 USC section 1734 solely to indicate this fact.

\section{References}

Andrews, N.C. and D.V. Faller. 1991. A rapid micropreparation technique for extraction of DN A-binding proteins from limiting numbers of mammalian cells. Nucleic Acids Res. 19: 2499.

Artavanis-Tsakonas, S., K. Matsuno, and M.E. Fortini. 1995. N otch signaling. Science 268: 225-232.

Azpiazu, N. and M. Frasch. 1993. Tinman and bagpipe: Two homeo box genes that determine cell fates in the dorsal mesoderm of Drosophila. Genes \& Dev. 7: 1325-1340.

Bailey, A.M. and J.W. Posakony. 1995. Suppressor of Hairless directly activates transcription of enhancer of split complex genes in response to $\mathrm{N}$ otch receptor activity. Genes \& Dev. 9: 2609-2622.

Blaumueller, C.M ., H. Qi, P. Zagouras, and S. Artavanis-Tsakonas. 1997. Intracellular cleavage of $\mathrm{N}$ otch leads to a heterodimeric receptor on the plasma membrane. Cell 90: 281-291.

Brand, A.H. and N . Perrimon. 1993. T argeted gene expression as a means of altering cell fates and generating dominant phe notypes. Devel opment 118: 401-415.

Brown, M.S. and J.L. Goldstein. 1997. The SREBP pathway: Regulation of cholesterol metabolism by proteolysis of a membrane-bound transcription factor. Cell 89: 331-340.

Campbell, M.E., J.W. Pal freyman, and C.M. Preston. 1984. Identification of herpes simplex virus DN A sequences which encode a trans-acting polypeptide responsible for stimulation of immediate early transcription. J. Mol. Biol. 180: 1-19.

Chou, T.B. and N. Perrimon. 1996. The autosomal FLP-DFS technique for generating germline mosaics in Drosophila mel anogaster. Genetics 144: 1673-1679.

Chou, T.B., E. Noll, and N. Perrimon. 1993. Autosomal $\mathrm{P}$ [ovoD1] dominant female-sterile insertions in Drosophila and their use in generating germ-line chimeras. Development 119: 1359-1369.

de Celis, J.F. and A. Garcia-Bellido. 1994. Modifications of the $\mathrm{N}$ otch function by A bruptex mutations in Drosophila melanogaster. Genetics 136: 183-194.

Doherty, D., G. Feger, S. Younger-Shepherd, L.Y. Jan, and Y.N . Jan. 1996. Delta is a ventral to dorsal signal complementary to Serrate, another $\mathrm{N}$ otch ligand, in Drosophila wing formation. Genes \& Dev. 10: 421-434.

Ebina, Y., Y. Takahara, F. Kishi, A. Nakazawa, and R. Brent. 1983. LexA protein is a repressor of the colicin El gene. J. Biol. Chem. 258: 13258-13261.

Ferrell Jr., J.E. and E.M. M achleder. 1998. The biochemical basis of an all-or-none cell fate switch in Xenopus oocytes. Science 280: 895-898.

FlyBase 1998. FlyBase: A Drosophila database. Nucleic Acid Res. 26: 85-88 http://flybase. bio.indiana.edu/.

Fortini, M.E. and S. Artavanis-T sakonas. 1994. The Suppressor of Hairless protein participates in $\mathrm{N}$ otch receptor signaling. Cell 79: 273-282.

Foster, G.G. 1975. N egative complementation at the N otch locus of Drosophila melanogaster. Genetics 81: 99-120.

Frise, E., J.A. Knoblich, S. Y ounger-Shepherd, L.Y. Jan, and Y.N . Jan. 1996. The Drosophila N umb protein inhibits signaling of the $\mathrm{N}$ otch receptor during cell-cell interaction in sensory organ lineage. Proc. Natl. Acad. Sci. 93: 11925-11932.

Gho, M., M. Lecourtois, G. Geraud, J.W. Posakony, and F. Schweisguth. 1996. Subcellular localization of Suppressor of Hairless in Drosophila sense organ cells during $\mathrm{N}$ otch signalling. Development 122: 1673-1682.

Greenwald, I. 1998. LIN-12/N otch signaling: Lessons from worms and flies. Genes \& Dev. 12: 1751-1762.

Gyuris, J., E. Golemis, H. Chertkov, and R. Brent. 1993. Cdi 1, a human $\mathrm{G} 1$ and $\mathrm{S}$ phase protein phosphatase that associates with Cdk2. Cell 75: 791-803.

Heitzler, P. and P. Simpson. 1991. The choice of cell fate in the epidermis of Drosophila. Cell 64: 1083-1092.

Hoppe, P.E. and R.J. Greenspan. 1986. Local function of the Notch gene for embryonic ectodermal pathway choice in Drosophila. Cell 46: 773-783.

Jarriault, S., C. Brou, F. Logeat, E.H. Schroeter, R. Kopan, and A. Israel. 1995. Signal ling downstream of activated mammalian N otch. Nature 377: 355-358.

Jennings, B., A. Preiss, C. Delidakis, and S. Bray. 1994. The $\mathrm{N}$ otch signalling pathway is required for Enhancer of split bHLH protein expression during neurogenesis in the Drosophila embryo. Development 120: 3537-3548.

Kao, H.-Y., P. Ordentlich, N. Koyano-N akagawa, Z. Tang, M Downes, C. Kintner, R.M. Evans, and T. Kadesch. 1998. A histone deacetylase corepressor complex regulates the N otch signal transduction pathway. Genes \& Dev. 12: 22692277.

Kato, H., Y. Taniguchi, H. Kurooka, S. M inoguchi, T. Sakai , S. N omura-Okazaki, K. Tamura, and T. Honjo. 1997. Involve ment of RBP-J in biological functions of mouse N otch 1 and its derivatives. Development 124: 4133-4141.

Kelley, M.R., S. Kidd, W.A. Deutsch, and M.W. Young. 1987. Mutations al tering the structure of epi dermal growth factorlike coding sequences at the Drosophila Notch locus. Cell 51: $539-548$.

Kidd, S. 1992. Characterization of the Drosophila cactus Iocus and analysis of interactions between cactus and dorsal proteins. Cell 71: 623-635.

Kidd, S., M.R. Kelley, and M.W. Young. 1986. Sequence of the Notch locus of Drosophila: Relationship of the encoded protein to mammalian clotting and growth factors. Mol. Cell. Biol. 6: 3094-3108.

Kidd, S., M .K. Baylies, G.P. Gasic, and M.W. Young. 1989. Structure and distribution of the Notch protein in Developing Drosophila. Genes \& Dev. 3: 1113-1129.

King, R.W., R.J. Deshaies, J.M. Peters, and M.W. Kirschner. 1996. How proteolysis drives the cell cycle. Science 274: 1652-1659.

Kopan, R., E.H. Schroeter, H. Weintraub, and J.S. Nye. 1996. Signal transduction by activated $\mathrm{mN}$ otch: Importance of proteolytic processing and its regulation by the extracellular domain. Proc. Natl. Acad. Sci. 93: 1683-1688.

Lecourtois, M. and F. Schweisguth. 1995. The neurogenic Suppressor of Hairless DN A-binding protein mediates the transcriptional activation of the enhancer of split complex genes triggered by N otch signaling. Genes \& Dev. 9: 2598-2608.

Lecourtois, M. and F. Schweisguth. 1998. Indirect evidence for Delta-dependent intracellular processing of $\mathrm{N}$ otch in Drosophila embryos. Curr. Biol. 8: 771-774.

Lieber, T., S. Kidd, E. Alcamo, V. Corbin, and M.W. Young. 1993. Antineurogenic phenotypes induced by truncated $\mathrm{N}$ otch proteins indicate a role in signal transduction and may point to a novel function for N otch in nuclei. Genes \& Dev. 7: 1949-1965.

Logeat, F., C. Bessia, C. Brou, O. LeBail, S. Jarriault, N .G. Sei- 
dah, and A. Israel. 1998. The N otch1 receptor is cleaved constitutively by a furin-like convertase. Proc. Natl. Acad. Sci. 95: 8108-8112.

Matsuno, K., R.J. Diederich, M.J. Go, C.M. Blaumueller, and S. Artavanis-Tsakonas. 1995. Deltex acts as a positive regulator of $\mathrm{N}$ otch signaling through interactions with the $\mathrm{N}$ otch ankyrin repeats. Development 121: 2633-2644.

Matsuno, K., M.J. Go, X. Sun, D.S. Eastman, and S. ArtavanisTsakonas. 1997. Suppressor of Hairless-independent events in $\mathrm{N}$ otch signaling imply novel pathway elements. Development 124: 4265-4273.

N ye, J.S. and R. Kopan. 1995. Developmental signaling. Vertebrate ligands for N otch. Curr. Biol. 5: 966-969.

Pan, D. and G.M. Rubin. 1997. Kuzbanian controls proteolytic processing of $\mathrm{N}$ otch and mediates lateral inhibition during Drosophila and vertebrate neurogenesis. Cell 90: 271-280.

Parks, A.L. and M.A.T. Muskavitch. 1993. Delta function is required for bristle organ determination and morphogenesis in Drosophila. Dev. Biol. 157: 484-496.

Perrimon, N., L. Engstrom, and A.P. M ahowald. 1984. Developmental genetics of the $2 \mathrm{E}-\mathrm{F}$ region the Drosophila $\mathrm{X}$ chromosome: A region rich in 'Developmentally important' genes. Genetics 108: 559-572.

Portin, P. 1975. Allelic negative complementation at the A bruptex locus of Drosophila mel anogaster. Genetics 81: 121-133.

Rebay, I., R.J. Fleming, R.G. Fehon, L. Cherbas, P. Cherbas, and S. Artavanis-Tsakonas. 1991. Specific EGF repeats of $\mathrm{N}$ otch mediate interactions with Delta and Serrate: Implications for N otch as a multifunctional receptor. Cell 67: 687-699.

Rebay, I., R.G. Fehon, and S. Artavanis-T sakonas. 1993. Specific truncations of Drosophila N otch define dominant activated and dominant negative forms of the receptor. Cell 74: 319329.

Roehl, H., M. Bosenberg, R. Blelloch, and J. Kimble. 1996. Roles of the RAM and ANK domains in signalling by the $C$. elegans GLP-1 receptor. EMBO J. 15: 7002-7012.

Rogers, S., R. Wells, and M. Rechsteiner. 1986. Amino acid sequences common to rapidly degraded proteins: The PEST hypothesis. Science 234: 364-368.

Schroeter, E.H., J.A. Kisslinger, and R. Kopan. 1998. Notch-1 signalling requires ligand-induced proteolytic release of intracellular domain. Nature 393: 382-386.

Schweisguth, F. and J.W. Posakony. 1992. Suppressor of Hairless, the Drosophila homolog of the mouse recombination signal-binding protein gene, controls sensory organ cell fates. Cell 69: 1199-1212.

- - - 1994. Antagonistic activities of Suppressor of Hairless and Hairless control alternative cell fates in the Drosophila adult epidermis. Development 120: 1433-1441.

Seydoux, G. and I. Greenwald. 1989. Cell autonomy of Iin-12 function in a cell fate decision in C. elegans. Cell 57: 12371245.

Stifani, S., C.M. Blaumueller, N.J. Redhead, R.E. Hill, and S. Artavanis-Tsakonas. 1992. Human homologs of a Drosophila Enhancer of Split gene product define a novel family of nuclear proteins. Nature Genet. 2: 119-127.

Struhl, G. and A. Adachi. 1998. Nuclear access and action of N otch in vivo. Cell 93: 649-660.

Struhl, G., K. Fitzgerald, and I. Greenwald. 1993. Intrinsic activity of the Lin-12 and $\mathrm{N}$ otch intracellular domains in vivo. Cell 74: 331-345.

Tamura, K., Y. Taniguchi, S. Minoguchi, T. Sakai, T. Tun, T. Furukawa, and T. Honjo. 1995. Physical interaction between a novel domain of the receptor $\mathrm{N}$ otch and the transcription factor RBP-J kappa/Su(H). Curr. Biol. 5: 1416-1423.

Wettstein, D.A., D.L. Turner, and C. Kintner. 1997. The Xeno- pus homolog of Drosophila Suppressor of Hairless mediates $\mathrm{N}$ otch signaling during primary neurogenesis. Devel opment 124: 693-702.

Wharton, K.A., K.M. Johansen, T. Xu, and S. Artavanis-Tsakonas. 1985. N ucleotide sequence from the neurogenic locus Notch implies a gene product that shares homology with protein containing EGF-like repeats. Cell 43: 567-581.

Williams, R., U. Lendahl, and M. Lardelli. 1995. Complementary and combinatorial patterns of $\mathrm{N}$ otch gene family expression during early mouse development. Mech. Dev. 53: 357368.

Xu, T. and G.M. Rubin. 1993. Analysis of genetic mosaics in developing and adult Drosophila tissues. Development 117: 1223-1237. 


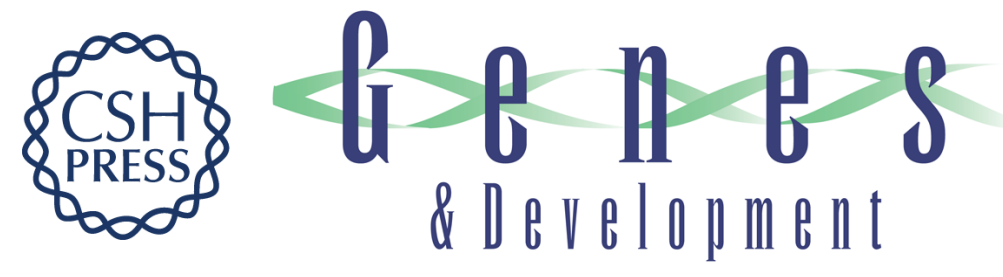

\section{Ligand-induced cleavage and regulation of nuclear entry of Notch in Drosophila melanogaster embryos}

Simon Kidd, Toby Lieber and Michael W. Young

Genes Dev. 1998, 12:

Access the most recent version at doi:10.1101/gad.12.23.3728

References

This article cites 60 articles, 32 of which can be accessed free at:

http://genesdev.cshlp.org/content/12/23/3728.full.html\#ref-list-1

\section{License}

Email Alerting

Receive free email alerts when new articles cite this article - sign up in the box at the top

Service right corner of the article or click here.

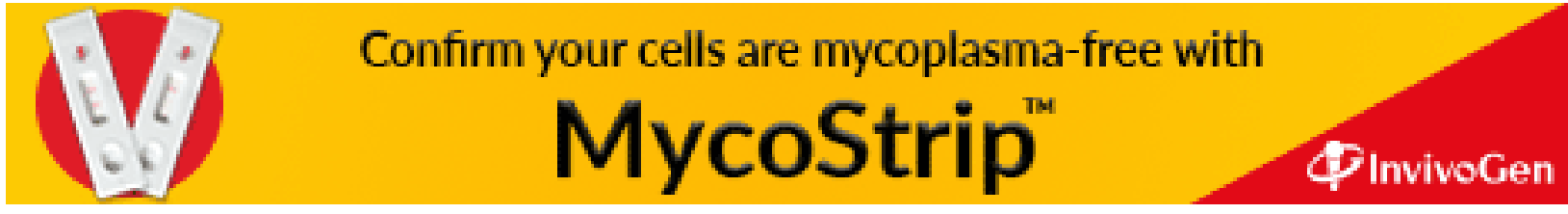

